\title{
Struktura urbanistyczna Smart City
}

\section{Smart City, urban structure issue}

\section{Streszczenie}

Prezentacja wyników badań dotyczących możliwości rozpoznania struktury Smart City poprzez wskaźniki urbanistyczne i analizę wizualną. Analiza miasta Songdo w Korei Południowej i porównanie go z innymi strukturami nierealizowanymi jako Smart City. Przedstawienie stworzonego algorytmu wykorzystującego dostępne publicznie dane, generującego trójwymiarowe modele miast i ich podział funkcjonalny. Próba odpowiedzi na pytanie, czy Smart City jest nowym, unikalnym trendem w urbanistyce.

Słowa kluczowe: Smart City, Songdo, Struktura urbanistyczna, Parametryzacja

\section{Abstract}

Research presentation of the Smart City structure recognition possibility by urban indicators and visible factors - built environment. Examination of Songdo Smart City in South Korea, and comparison with other cities that weren't designed as Smart City. Presentation of parametric algorithm which is using open source data, written to get the results of examination. Trial to answer is the Smart City new, unique trend in creation of urban environment, or only way of city administration.

Keywords: Smart City, Songdo, Urban Structure, Parametric Design 


\section{WSTĘP}

Pojęciem, które w przeciągu kilku ostatnich lat jest najczęściej powtarzane w kontekście kierunku rozwoju współczesnych zespołów urbanistycznych, jest bez wątpienia "Smart City”. Założenia te z powodzeniem powstały w krajach tak zróżnicowanych jak Brazylia, Stany Zjednoczone, Zjednoczone Emiraty Arabskie, Korea Południowa czy Szkocja.

To właśnie w południowo-wschodniej Azji, w jednym z najbardziej rozwiniętych technologicznie państw na świecie - Korei Południowej, został zrealizowany największy projekt finansowany ze środków niepublicznych, zakładający stworzenie od podstaw pełnowartościowego, nowoczesnego miasta, które miało być modelowym przykładem Smart City. Chodzi o Songdo, miasto zlokalizowane w odległości około $65 \mathrm{~km}$ od centrum Seulu na powierzchni ponad 2800 ha terenu odzyskanego od Morza Żółtego.

Według głównych założeń inwestorów - spółki Gale International ${ }^{1}$ and POSCO E\&C JV oraz architektów: NSIC - twórców Master Planu oraz wielu innych biur architektonicznych takich jak min. początkowo OMA, a docelowo KPF Architects ${ }^{2}$ i Kunwon Architects odpowiedzialnych za projekt IBD Songdo, tylko w dzielnicy IBD miało znajdować się $3 \mathrm{mln} \mathrm{m}^{2}$ powierzchni mieszkaniowej, $5 \mathrm{mln} \mathrm{m}^{2}$ powierzchni biurowej i ok. $1 \mathrm{mln} \mathrm{m}^{2}$ powierzchni usługowo-handlowej ${ }^{3}$, a 65-piętrowa wieża - Północnoazjatycka Wieża Handlu miała stać się najwyższym budynkiem w Korei Południowej ${ }^{4}$. Cały projekt miał być zrealizowany w latach 2003-2020. W mieście dodatkowo miały znaleźć się także elementy tworzące indywidualny charakter struktury miejskiej, a w rzeczywistości symbole będące charakterystyczne dla innych sławnych miast - paryski bulwar, weneckie kanały czy nowojorski Central Park, a dodatkową atrakcją miało być między innymi rozległe pole golfowe.

Warto zaznaczyć, że aż 106 budynków, o łącznej powierzchni 2,2 mln m², miało spełniać standardy certyfikacji LEED przyznawanej przez U.S. Green Building Council. Dzięki temu wspomniana powierzchnia biurowa w Songdo stanowi obecnie $40 \%$ całkowitej certyfikowanej przez LEED powierzchni biurowej w całej Korei Południowej. Budżet przewidziany na realizacje w przeciągu 10 lat tej inwestycji miał sięgać 40 miliardów dolarów, pozycjonując je jako jedno z najdroższych w historii przedsięwzięć budowlanych objętych jednym spójnym projektem.

Inwestycja została wyposażona w najnowsze technologie teleinformatyczne, np. umożliwiające wideokonferencje pomiędzy wszystkimi najważniejszymi instytucjami, organami miejskimi, a także poszczególnymi mieszkaniami. Zdecydowanie bardziej kluczowa okazała się jednak związana z rozwojem dostępu do Internetu i GPS możliwość obserwacji, śledzenia mieszkańców, pozyskiwania danych, pozbawiona powiązania z ich tożsamością, możliwość analizy oraz wyciągania wniosków mających docelowo wpłynąć na zwiększenie komfortu życia. Wspomniana technologia została określona mianem - Internet of Things (IoT).

Jako architekt i urbanista staram się odpowiedzieć na pytanie jak bardzo na rzeczywisty odbiór środowiska zbudowanego ma wpływ typologia struktury urbanistycznej i jej założenia 
programowe. Czy Smart City charakteryzuje się szczególnymi wskaźnikami urbanistycznymi, czy może być świadomie odbierane na płaszczyźnie przestrzennej. Czy istnieją podstawy, żeby stwierdzić, że Smart City jest następnym po postmodernizmie w urbanistyce i ruchu New Urbanism, nowym i autonomicznym sposobem kształtowania miast, czy pozostanie jedynie zjawiskiem związanym z postępem rozwiązań teleinformatycznych i centralnym zarządzaniem strukturami miejskimi i ich elementami jak transport publiczny, usługi publiczne, energetyka, media i inne.

\section{METODA BADAWCZA}

W badaniach wykorzystane zostały udostępnione na dane, na podstawie których został wygenerowany trójwymiarowy model miasta Songdo, a następnie przeprowadzone zostały wizualne analizy struktury zabudowy i badania poszczególnych fragmentów miasta w celu określenia indywidualnych wskaźników urbanistycznych takich jak: intensywność zabudowy (In), powierzchnia ogólna (Pog), powierzchnia terenu inwestycji (Tn), powierzchnia zabudowy (Pzab), średnia ważona liczba kondygnacji (k), udział powierzchni zabudowy w badanym terenie (Gzab), liczba mieszkańców (Lm), gęstość zaludnienia (Gm), powierzchnia ogólna na 1 mieszkańca $(\mathrm{Wm})$, których analiza w sposób pośredni prowadzi do odpowiedzi na powyżej przedstawione pytania.

Poniżej przedstawione zostały zależności pomiędzy poszczególnymi wskaźnikami:

$$
\text { In }=\frac{\text { Pog }}{T n} k=\frac{\text { Pog }}{\text { Pzab }} G z a b=\frac{\text { Pzab }}{T n}=\frac{\text { In }}{k} \quad W m=\frac{\text { Pog }}{L m} G m=\frac{\mathrm{Lm}}{T n}=\frac{\text { In }}{W m}
$$

\subsection{METODA GENEROWANIA MODELU TRÓJWYMIAROWEGO}

Na podstawie zaimportowanej z portalu openstreetmap.org bazy danych dotyczącej prezentowanego obszaru (il. 1) został wygenerowany trójwymiarowy model miasta. Algorytm generujący został stworzony w programie Grasshopper będącym parametrycznym rozszerzeniem programu Rhino.

Stworzony algorytm (il. 2) składa się z 4 części. Na początku określona została ścieżka donpliku .xml. Określona została także zamknięta krzywa, dzięki której istnieje możliwość uruchamiania algorytmu dla mniejszych fragmentów bazy.

Wybrane dane wprowadzane są do filtrów pozwalających na wybór informacji. Do każdej z kategorii przydzielana jest indywidualna barwa a następnie przeprowadzany jest proces generowania, w pierwszej kolejności płaszczyzn płaskich, następnie na ich podstawie tworzenia kubatur o właściwej dla danego obiektu ilości kondygnacji, dodatkowo sumowane są powierzchnie zabudowy i powierzchnie użytkowe wszystkich obiektów objętych badaniem. Całość została zaprezentowana w formie graficznej (il. 3). 
Kolejna część algorytmu dotyczy obliczania udziałów procentowych wspomnianych powyżej powierzchni o poszczególnych funkcjach w stosunku do całkowitej badanej sumy powierzchni. W tej części przeprowadzane są także obliczenia wybranych wskaźników urbanistycznych

Ostatnią część stanowi wygenerowanie wykresu kołowego będącego interpretacją graficzną wyników badań. Ostatecznie po wykonaniu algorytmu w przestrzeni roboczej programu generowany jest trójwymiarowy model badanego obszaru (il. 4).

W celu weryfikacji prawdziwości wygenerowanego na podstawie bazy danych trójwymiarowego modelu struktury urbanistycznej zostało wykonane porównanie zdjęcia satelitarnego, które zostało wykonane w 2017 roku, pobranego z portalu Google Maps (il. 5) $z$ analogicznym ujęciem perspektywicznym modelu (il. 6).

Z grafik wynika, że pomimo nieznacznych rozbieżności w kształcie niektórych budynków, model przedstawia faktyczny stan zainwestowania i może służyć do przeprowadzenia badań, których wyniki będą prawdziwą interpretacją środowiska zbudowanego, a baza danych, na podstawie której generowany jest model jest stale aktualizowana i nie posiada nieaktualnych treści.

\section{ANALIZA STRUKTURY URBANISTYCZNEJ MIASTA SONGDO}

\subsection{LOKALIZACJA I ROZWÓJ}

Na ilustracjach 7 i 8 przedstawione zostało porównanie grafik wykonanych na bazie zdjęć satelitarnych udostępnionych przez firmę Google w aplikacji timelapse. Pierwsza z nich przedstawia sytuację z 1986 roku, a druga z roku 2016.

Ilustracje ukazują zmiany i rozwój struktur urbanistycznych na przestrzeni 30 lat. Należy mieć na uwadze, że prace związane z realizacją omawianej inwestycji zostały rozpoczęte w roku 1993. Na lokalizacje Songdo miało wpływ wiele czynników, jednak najbardziej strategicznym była decyzja o budowie portu lotniczego Incheon, który stał się głównym lotniskiem Korei Południowej i bramą na świat, powodującą rozwój ekonomiczny.

\subsection{ANALIZA STRUKTURY ZABUDOWY}

Wygenerowany model miasta umożliwia przeprowadzenie analizy struktury urbanistycznej (il. 9). Na rysunku została przedstawiona w formie rzutu typologia zrealizowanej zabudowy. Na ilustracji pozbawionej informacji dotyczącej wysokości budynków można błędnie ocenić sposób i charakter zainwestowania terenów. Na pierwszy plan wysuwają się budynki wielko powierzchniowe, usługowe, kulturowe, konferencyjne, a ich kumulacja w środku i otoczenie rozdrobnioną zabudową mogłyby sugerować, że to właśnie tam znajduje się centrum miasta otoczone kilkukondygnacyjną zabudową mieszkaniową. Na południu, gdzie również jest z zabudowa wielkopowierzchniowa, mogłyby znajdować się obiekty 
przemysłowe, produkcyjne. Taka interpretacja sugeruje, że miasto zostało zaprojektowane w oparciu o idee strefowości, i model miasta przemysłowego Toniego Garniera 5 .

Interpretowane jako mieszkaniowe, punktowe zespoły zabudowy przypominają swoją strukturą urbanistyczną modernistyczne osiedla powstałe w oparciu o założenia pierwszej karty Ateńskiej i proklamowane przez Le Corbusiera hasła „słońce, przestrzeń, zieleń”6. Ciężko doszukać się tutaj charakterystycznych dla postmodernistycznej struktury urbanistycznej kwartałów zabudowy z półprywatnymi wnętrzami, placów, czy wyraźnie zaakcentowanych fasadami traktów ulic.

Wykonana analiza zacienienia (il. 10) pozwala na bardziej świadomy odbiór. Obszary wstępnie oceniane jako zainwestowane w mniejszym stopniu stanowią główną tkankę miejską. W centrum zlokalizowane są niskie pawilony, bardzo dobrze doświetlone, wkomponowane w teren rekreacyjny. Przedstawiony schemat poddaje pod wątpliwość ideę strefowania, wskazując, że zarówno zabudowa biurowa, jak i mieszkaniowa kreowane są w bardzo podobny sposób, niską zabudowę stanowią ewentualne hale produkcyjne, obiekty handlowe, budynki edukacji czy pawilony usługowe. Nie sposób doszukać się dzielnicy willowej. Tak mocna koncentracja zabudowy wysokiej jest charakterystyczna dla idei miasta oszczędnego, wydajnego, ekonomicznego, a Songdo wydaje się być jej reprezentantem.

Powstaje pytanie, czy Songdo bliżej do modernizmu czy postmodernizmu. Czy postulowane przez autorów projektu powiązanie środowiska miejskiego z naturalnym powstało na bazie teorii miasta ogrodu Ebenezera Howarda, czy większą inspiracją stały się działania braci Johna i Fredericka Olmsted? Pojawiają się opinie, że miasto zostało zaprojektowane na kształt Nowego Jorku. Niestety taka ocena wydaje się być błędna ze względu na omawianą, odmienną strukturę zabudowy, morfologie ulic i skalę założenia, a jedyne, co wiąże te dwa miasta, to fakt posiadania w swoim centrum parku i nagromadzenie wysokiej zabudowy. Sami projektanci wskazują jedynie na fakt inspiracji Manhattanem, co w żaden sposób nie powinno być podstawą do tak powierzchownej oceny. W koreańskim przykładzie całość została zaprojektowana od zera, przestrzeń została zaprogramowana w najbardziej wydajny, efektywny, efektowny ale także komfortowy i zdrowy sposób.

W celu przeprowadzenia analizy środowiska zbudowanego został wyodrębniony fragment, ograniczony szerszymi traktami ulic, który otrzymał roboczą nazwę jednostki sąsiedzkiej. Na analizie zacieniania (il. 11) wyraźnie widać, że typologia zabudowy różni się względem siebie na obrzeżach i wewnątrz. Budynki zlokalizowane bliżej drogi pomimo swojego punktowego charakteru posiadają kilkukondygnacyjną podbudowę, która charakterystyczna jest dla funkcji usługowej i handlowej, a z niej wyrastają punktowo wysokościowce mieszczące funkcje biurowe. Budynki wewnętrzne są już typowymi punktowcami mieszkalnymi, zakomponowanymi w przestrzeni zielonej. Zlokalizowany w samym centrum badanej struktury budynek o większej powierzchni pełni funkcje edukacyjną i skierowany jest do mieszkańców jednostki.

Taka analiza może prowadzić do wniosku, że jednostka przyjmuje formę urbanistycznego megakwartału, obrys kształtuje zabudowa definiująca w dolnych kondygnacjach pierzeje 
ulicy, stając się naturalną barierą akustyczną, natomiast wnętrze, stanowi rozproszona zabudowa punktowa, która zlokalizowana jest w półprywatnej przestrzeni względem reszty miasta.

Przedstawiony wniosek wskazywałby na innowacyjne podejście w planowaniu, na swoistą fuzje postulatów modernistycznych z postmodernistycznymi możliwą poprzez zmianę skali, w którym charakterystyczne dla danych trendów rozwiązania znalazły zastosowanie monofunkcyjna, punktowa lub liniowa, wolna zabudowa modernistyczna, została zamknięta w postmodernistycznym, wielofunkcyjnym, systematyzującym zabudowę kwartale. Na tej podstawie można powiedzieć, że przysłowiowy kwartał staje się autonomiczną jednostką miastem w mieście, dzięki czemu istnieje możliwość swobodnego rozwoju miasta poprzez multiplikacje jednostek $\mathrm{w}$ ramach spójnego projektu - elementu łączącego - kręgosłupa w formie parku, bulwarów, terenów rekreacyjnych (il. 12).

Posiadanie cyfrowego modelu miasta daje możliwość tworzenia ujęć z perspektywy człowieka wewnątrz badanej struktury. Wykonane ujęcia przedstawiające widoki z zewnątrz (il. 13) i wewnątrz (il. 14) omawianej jednostki, wydają się potwierdzać sformułowaną w wyniku przeprowadzonych analiz tezę o organizacji zabudowy przy zewnętrznych granicach badanej jednostki w sposób pierzejowy oraz o bardziej rozproszonej zabudowie wnętrza.

\subsection{WSKAŹNIKI I BADANIA URBANISTYCZNE W SONGDO - CAŁE MIASTO}

Badania mające na celu otrzymanie wskaźników urbanistycznych zostały wykonane dla całego miasta i jego fragmentów, co pozwoli na analizę wartości w różnych skalach - całej struktury urbanistycznej, dzielnicy i kwartału zabudowy oraz określenie dla nich udziału procentowego powierzchni poszczególnych funkcji w kontekście sumy powierzchni zabudowy budynków jak i sumy powierzchni całkowitej budynków znajdujących się na badanym terenie, ich wyniki zostały zaprezentowane w formie dwóch wykresów kołowych.

Wyniki badania całego miasta (il.15) uwzględniające wielkość populacji na poziomie 250 tys.:

\begin{tabular}{|c|c|c|c|c|c|c|c|}
\hline $\begin{array}{c}\text { Pow. } \\
\text { terenu } \\
\text { inwestycji }\end{array}$ & Pow. ogólna & $\begin{array}{c}\text { Int. } \\
\text { zab. }\end{array}$ & $\begin{array}{c}\text { Średnia } \\
\text { ważona } \\
\text { liczba } \\
\text { kondygn. }\end{array}$ & $\begin{array}{c}\text { Udział } \\
\text { pow. } \\
\text { zabudowy }\end{array}$ & $\begin{array}{c}\text { Pow. wolna } \\
\text { od zabudowy } \\
\text { na } 1 \mathrm{~m}^{2} \\
\text { pow. ogólnej }\end{array}$ & $\begin{array}{c}\text { Pow. } \\
\text { ogólna na } \\
\text { mieszkańca }\end{array}$ & $\begin{array}{c}\text { Gęstość } \\
\text { zaludnienia } \\
\text { na } \mathrm{km}^{2}\end{array}$ \\
\hline $2830 \mathrm{ha}$ & $14,75 \mathrm{mln} \mathrm{m}^{2}$ & 0,52 & 9,44 & $5,53 \%$ & $1,8 \mathrm{~m}^{2}$ & $62,44 \mathrm{~m}^{2}$ & 5305 os. \\
\hline
\end{tabular}

Na uwagę zasługuje istotna różnica pomiędzy wynikami w udziale procentowym powierzchni zabudowy i powierzchni całkowitej. Na wykresie nr 1 (il. 16) widzimy, że wyróżnić można 3 najważniejsze kategorie. Najwięcej zajęte jest przez zabudowę usługowo-biurowo-handlową - 34\%, następnie przemysłowo-produkcyjną - 27\%, (przemysł zaawansowany, niegenerujący większych zanieczyszczeń czy szkód w środowisku), a 22\% stanowi zabudowa mieszkaniowa. 
Inaczej przedstawia się sytuacja na wykresie nr 2 (il. 17). Pomimo że wspomniane powyżej 3 główne kategorie są identyczne, ich kolejność oraz różnica w wyniku jest inna. Liderem z wynikiem 63\% jest zabudowa mieszkaniowa, następnie zabudowa usługowo-biurowo-handlowa - 18\%, a zabudowa przemysłowo-produkcyjna jedynie $10 \%$.

Analizując wyniki z wartościami wskaźników urbanistycznych, jak intensywność zabudowy - 0,52, udział powierzchni zabudowy - 5,53\% i gęstość zaludnienia ok. 5,3 tys. ludzi na $\mathrm{km}^{2}$, można stwierdzić, że projektanci postanowili poszukać balansu pomiędzy terenami rekreacyjnymi, parkowymi i obszarami zainwestowanymi przez zastosowanie punktowej zabudowy wysokościowej, przede wszystkim mieszkaniowej, która pomimo że nie zajmuje najwięcej miejsca, to jej powierzchnia stanowi zdecydowanie dominującą funkcję. Z powyższych wyników nie bylibyśmy w stanie ocenić zorganizowania struktury. Dzięki widokom z modelu możemy stwierdzić że twórcy, kierując się ideą miasta oszczędnego i wydajnego, postanowili dążyć do jej maksymalnej koncentracji.

\subsection{WSKAŹNIKI I BADANIA URBANISTYCZNE W SONGDO-DZIELNICA IBD}

Wewnątrz miasta znajduje się dzielnica biznesowa - IBD Songdo. Zakres opracowania został przyjęty zgodnie z jej granicą a dyspozycja przestrzenna została zaprezentowana na ujęciu (il. 18). Wyniki odnoszą się do obecnego stanu zainwestowania, a nie do docelowych założeń projektowych.

Wyniki badania uwzględniające wielkość populacji na poziomie 101 tys.:

\begin{tabular}{|c|c|c|c|c|c|c|c|}
\hline $\begin{array}{c}\text { Pow. } \\
\text { terenu } \\
\text { inwestycji }\end{array}$ & Pow. ogólna & $\begin{array}{c}\text { Int. } \\
\text { zab. }\end{array}$ & $\begin{array}{c}\text { Średnia } \\
\text { ważona } \\
\text { liczba } \\
\text { kondygn. }\end{array}$ & $\begin{array}{c}\text { Udział } \\
\text { pow. } \\
\text { zabudowy }\end{array}$ & $\begin{array}{c}\text { Pow. wolna } \\
\text { od zabudowy } \\
\text { na } 1 \mathrm{~m}^{2} \\
\text { pow. ogólnej }\end{array}$ & $\begin{array}{c}\text { Pow. } \\
\text { ogólna na } \\
\text { mieszkańca }\end{array}$ & $\begin{array}{c}\text { Gęstość } \\
\text { zaludnienia } \\
\text { na km² }\end{array}$ \\
\hline 600 ha & $5,4 \mathrm{mln} \mathrm{m}^{2}$ & 0,97 & 14 & $6,85 \%$ & $1,035 \mathrm{~m}^{2}$ & $62,44 \mathrm{~m}^{2}$ & 11001 os. \\
\hline
\end{tabular}

Na wykresach nr 1 i nr 2 (il. 19 i 20) widzimy diametralną różnicę pomiędzy wynikami udziału procentowego danej funkcji w sumie powierzchni zabudowy i całkowitej. Najwięcej powierzchni - 60\%, zajmuje zabudowa usługowo-biurowo-handlowa, a jedynie $30 \%$ mieszkaniowa, następnie funkcje związane z oświatą - 7\% i obiekty zamieszkania czasowego $-2 \%$.

Inaczej przedstawia się sytuacja na drugim wykresie (il. 20). Widzimy, że suma powierzchni całkowitej mieszkaniowej stanowi 71\%, a suma powierzchni usługowo-biurowo-handlowej to $23 \%$, oświata zajmuje $4 \%$ a obiekty zamieszkania czasowego $1 \%$. Wyniki te, wskazywałyby na rozróżnienie zabudowy pomiędzy mieszkaniową - wysokościową, punktową, a zabudową usługowo-biurowo-handlową, niższą, rozległą, charakterystyczną, centrów kongresowych i obiektów handlowych. 
Warto zauważyć wzrost wartości intensywności zabudowy, średniej ważonej liczby kondygnacji i gęstości zaludnienia. Wyniki te oznaczają, że dzielnica w tym momencie jest dwukrotnie bardziej zurbanizowana względem całego miasta.

Należy zwrócić uwagę, że podobnie jak przy koncentracji zabudowy dla całego miasta takie rozwiązanie zostało zastosowane także przy kształtowaniu struktury badanej dzielnicy, na pierwszy plan wybija zabudowany kwartał na północy a został on zbalansowany polem golfowym i dużym parkiem ze zbiornikiem wodnym, który domknięty jest centrum konferencyjnym.

\subsection{WSKAŹNIKI I BADANIA URBANISTYCZNE W SONGDO - DZIELNICA IBD - KWARTA $Ł$ ZABUDOWY}

Najintensywniej zabudowaną część dzielnicy stanowi kwartał zabudowy (il. 21) mogący być interpretowany w przestrzeni jako autonomiczna jednostka sąsiedzka posiadająca własny ośrodek oświaty, elementy węzłów usługowo handlowych i dominującą, w aspekcie analizy wizualnej ujęcia perspektywicznego modelu, zabudowę mieszkaniową.

Wyniki badania kwartału dzielnicy IBD, wielkość populacji na poziomie 29 tys.:

\begin{tabular}{|c|c|c|c|c|c|c|c|}
\hline $\begin{array}{c}\text { Pow. } \\
\text { terenu } \\
\text { inwestycji }\end{array}$ & Pow. ogólna & $\begin{array}{c}\text { Int. } \\
\text { zab. }\end{array}$ & $\begin{array}{c}\text { Średnia } \\
\text { ważona } \\
\text { liczba } \\
\text { kondygn. }\end{array}$ & $\begin{array}{c}\text { Udział } \\
\text { pow. } \\
\text { zabudowy }\end{array}$ & $\begin{array}{c}\text { Pow. wolna } \\
\text { od zabudowy } \\
\text { na } 1 \mathrm{~m}^{2} \\
\text { pow. ogólnej }\end{array}$ & $\begin{array}{c}\text { Pow. } \\
\text { ogólna na } \\
\text { mieszkańca }\end{array}$ & $\begin{array}{c}\text { Gęstość } \\
\text { zaludnienia } \\
\text { na } \mathrm{km}^{2}\end{array}$ \\
\hline $133 \mathrm{ha}$ & $3,4 \mathrm{mln} \mathrm{m}^{2}$ & 2,56 & 15 & $16,65 \%$ & $0,32 \mathrm{~m}^{2}$ & $62,44 \mathrm{~m}^{2}$ & 16014 os. \\
\hline
\end{tabular}

Pomimo wrażenia gęsto zabudowanego terenu, wysokiej wartości intensywności zabudowy - ok. 2,5 i gęstości zaludnienia przekraczającej 16 tys. osób na 1 km², powierzchnia zabudowy stanowi jedynie 16,65\% powierzchni. Uwzględniając że znajdują się tam trakty komunikacji, wciąż większość terenu otrzymuje możliwość zainwestowania na cele rekreacyjne lub parkowe, wpływając bardzo korzystnie na jakość życia mieszkańców. Przestrzenie te jak opisuje prof. Gehl dają „możliwość spotykania sąsiadów i współpracowników, często w związku z codziennym przemieszczaniem się, stwarza to nieocenioną okazję do nawiązywania i późniejszego podtrzymywania znajomości w sposób luźny i niewymagający"8.

Porównanie wyników kwartału (il. 22, 23) do ich odpowiedników dla całej dzielnicy IBD wskazuje, że pomimo różnic w sumach poszczególnych powierzchni o różnych funkcjach, wartości udziałów procentowych względem siebie pozostają zbliżone. Taka analiza może prowadzić do wniosku, że twórcom zależało na tym, żeby w różnych skalach został zachowany balans pomiędzy poszczególnymi funkcjami oraz występowało zjawisko zrównoważonego rozwoju. 


\section{ANALIZA STRUKTURY URBANISTYCZNEJ WYBRANYCH ZESPOŁÓW MIEJSKICH NA TLE ZABUDOWY SONGDO}

Zrozumienie wyników przedstawionych badań, wartości poszczególnych wskaźników urbanistycznych byłoby trudne bez porównania do przestrzeni objętych jednym, spójnym projektem, niebędących określane mianem Smart City. Powstaje pytanie, czy autorzy pierwszego, zrealizowanego od podstaw Smart City - Songdo, około 60 lat po publikacji założeń Karty Ateńskiej i powstałych w licznych realizacji modernistycznych struktur urbanistycznych, szczególnie w Europie wschodniej i w USA oraz późniejszej ich krytyce ze strony urbanistów kształtujących ruch postmodernistyczny w urbanistyce, mogli chcieć dać szanse realizacji ideałom, które przyświecały Le Corbusierowi, wykorzystując najnowsze technologie i unikając błędów z przeszłości, korzystając z faktu, że budują miasto na obszarze pozbawionym kontekstu, mając na uwadze postulaty Kevina Lyncha, który pisał, że strukturę miejską charakteryzuje trójwymiarowa rozciągłość i czterowymiarowa pojemność ${ }^{9}$.

\subsection{OSIEDLE TYSIĄCLECIA W KATOWICACH, POLSKA}

W tym celu analizie poddane zostało katowickie osiedle tysiąclecia (il. 24) autorstwa architektów: Henryka Buszki, Aleksandra Franty, Mariana Dziewońskiego i Tadeusza Szewczyka wzniesione w latach 1961-1990. Przykład ten wydaje się być najbardziej reprezentatywny ze względu na skalę i charakter inwestycji. Na powierzchni 188 ha powstała struktura, w której mieszka około 23500 ludzi.

Wyniki wskaźników urbanistycznych ${ }^{10}$ dla Osiedla Tysiąclecia uwzględniające przybliżoną wielkość jego populacji na poziomie 23,5 tys.:

\begin{tabular}{|c|c|c|c|c|c|c|c|}
\hline $\begin{array}{c}\text { Pow. } \\
\text { terenu } \\
\text { inwestycji }\end{array}$ & Pow. ogólna & $\begin{array}{c}\text { Int. } \\
\text { zab. }\end{array}$ & $\begin{array}{c}\text { Średnia } \\
\text { ważona } \\
\text { liczba } \\
\text { kondygn. }\end{array}$ & $\begin{array}{c}\text { Udział } \\
\text { pow. } \\
\text { zabudowy }\end{array}$ & $\begin{array}{c}\text { Pow. wolna } \\
\text { od zabudowy } \\
\text { na } 1 \mathrm{~m}^{2} \\
\text { pow. ogólnej }\end{array}$ & $\begin{array}{c}\text { Pow. } \\
\text { ogólna na } \\
\text { mieszkańca }\end{array}$ & $\begin{array}{c}\text { Gęstość } \\
\text { zaludnienia } \\
\text { na km² }\end{array}$ \\
\hline 188 ha & $1,975 \mathrm{mln} \mathrm{m}^{2}$ & 1,05 & 4,83 & $18,0 \%$ & $0,78 \mathrm{~m}^{2}$ & Ok. $55 \mathrm{~m}^{2}$ & 12480 os. \\
\hline
\end{tabular}

Porównując wyniki z wartościami dla dzielnicy IBD w Songdo, należy dojść do wniosku, że pomimo zbliżonej intensywności zabudowy i gęstości zaludnienia na $1 \mathrm{~km}^{2}$ zabudowa w Smart City jest wyższa, a jej powierzchnia zabudowy około 2,5 razy niższa.

Odnosząc się do wyników dla kwartału zabudowy w Songdo, który zamieszkuje zbliżona liczba ludzi, należy zauważyć, że udział powierzchni zabudowy dla obydwóch struktur jest zbliżony jednak pozostałe wartości są znacząco różne. Intensywność zabudowy w badanym kwartale podobnie jak średnia ważona liczba kondygnacji jest wyższa niż w Osiedlu Tysiąclecia, a to powoduje wzrost gęstości zaludnienia o około $30 \%$. 
Wyniki te potwierdzają kierowanie się twórców Songdo zasadami zrównoważonego rozwoju, ideami miasta wydajnego i oszczędnego, których główną cechą jest maksymalna koncentracja w celu pozostawienia możliwie dużej powierzchni wolnej od zabudowy.

\subsection{STUYVESANT TOWN - PETER COOPER VILLAGE, MANHATTAN, NOWY JORK, USA}

Poszukując odpowiedzi na pytania postawione na wstępie, należy odpowiedzieć, w jaki sposób były lub są obecnie kształtowane większe struktury urbanistyczne, w miejscach posiadających najwyższe wartości gęstości zaludnienia na świecie, które mogły służyć za przykład dla Songdo.

W tym celu analizie poddany został zaprojektowany przez Roberta Mosesa i wzniesiony w latach 1942-1947 zespół znajdujący się na Manhattanie - Stuyvesant Town - Peter Cooper Village (il. 25). Jest to jeden z niewielu istniejących w tym miejscu przykładów realizacji na powierzchni około 39 ha w formie zorganizowanej struktury urbanistycznej, zaprojektowanych w duchu modernizmu budynków wielorodzinnych zatopionych w zieleni, która otoczona jest charakterystyczną dla Nowego Jorku zabudową.

Wyniki wskaźników urbanistycznych dla Stuyvesant Town - Peter Cooper Village uwzględniające wielkość populacji $20250^{11}$ :

\begin{tabular}{|c|c|c|c|c|c|c|c|}
\hline $\begin{array}{c}\text { Pow. } \\
\text { terenu } \\
\text { inwestycji }\end{array}$ & Pow. ogólna & $\begin{array}{c}\text { Int. } \\
\text { zab. }\end{array}$ & $\begin{array}{c}\text { Średnia } \\
\text { ważona } \\
\text { liczba } \\
\text { kondygn. }\end{array}$ & $\begin{array}{c}\text { Udział } \\
\text { pow. } \\
\text { zabudowy }\end{array}$ & $\begin{array}{c}\text { Pow. wolna } \\
\text { od zabudowy } \\
\text { na } 1 \mathrm{~m}^{2} \\
\text { pow. ogólnej }\end{array}$ & $\begin{array}{c}\text { Pow. } \\
\text { ogólna na } \\
\text { mieszkańca }\end{array}$ & $\begin{array}{c}\text { Gęstość } \\
\text { zaludnienia } \\
\text { na } \mathrm{km}^{2}\end{array}$ \\
\hline $39 \mathrm{ha}$ & $0,94 \mathrm{mln} \mathrm{m}^{2}$ & 2,4 & 13 & $22 \%$ & $0,32 \mathrm{~m}^{2}$ & Ok. $43 \mathrm{~m}^{2}$ & 51910 os. \\
\hline
\end{tabular}

W tym przypadku ze względu na brak sąsiadującej większej przestrzeni wolnej od zabudowy powyższe wyniki porównane zostaną z wartościami wskaźników dla kwartału dzielnicy IBD w Songdo.

Na uwagę zasługuje wysoka wartość gęstości zaludnienia, która jest niespełna 3,5-krotnie wyższa niż w Smart City. Pomimo drastycznej różnicy, intensywność zabudowy i średnia liczba kondygnacji nie wykazują wyraźnych rozbieżności. Znacząco wzrósł (o około 29,5\%) udział powierzchni zabudowy w badanym terenie oraz spadła powierzchnia ogólna przypadająca na 1 mieszkańca.

Jest to jeden z najbardziej wydajnych projektów struktur modernistycznych ze względu na swoją dużą gęstość zabudowy i fakt, że przez tyle lat osiedle nie zostało zrównane z ziemią a w jego miejscu nie powstały drapacze chmur. Świadczy to o bardzo dobrym warsztacie twórców projektu, który spełnia oczekiwania nawet po 70 latach w miejscu architektonicznej rewii mody. 


\subsection{RIESELFELD, FRYBURG, NIEMCY}

Ze względu na charakter zabudowy w Songdo do tej pory analizowane były przykłady będące reprezentantami trendu modernizmu w urbanistyce. Aby analiza Smart City mogła doprowadzić do wysunięcia pełnych wniosków, badaniu została poddana dzielnica będąca przykładem postmodernistycznym, odwołująca się do wzorców zabudowy kwartałowej, budującej pierzeje ulicy i place miejskie.

Rieselfeld w niemieckim Fryburgu (il. 26) swój obecny kształt zawdzięcza wynikowi konkursu na projekt jednostki mieszkaniowej autorstwa min. architekta Heinricha Böwera. Pierwsze budynki były oddawane w 1994 roku, a dzielnice zamieszkuje 9 tys. ludzi. Twórcom zależało na stworzeniu koncepcji realizującej założenia zrównoważonego rozwoju i powiązania zabudowy z naturą. Bazując na analizie wizualnej, można zauważyć zabudowę kwartałową, budowanie pierzei arterii komunikacyjnych, podkreślenie centrum w formie placu miejskiego oraz tereny parkowe otaczające obiekty o funkcji edukacyjnej.

Wyniki wskaźników urbanistycznych uwzględniające przybliżoną wielkość populacji na poziomie 9 tys.:

\begin{tabular}{|c|c|c|c|c|c|c|c|}
\hline $\begin{array}{c}\text { Pow. } \\
\text { terenu } \\
\text { inwestycji }\end{array}$ & Pow. ogólna & $\begin{array}{c}\text { Int. } \\
\text { zab. }\end{array}$ & $\begin{array}{c}\text { Średnia } \\
\text { ważona } \\
\text { liczba } \\
\text { kondygn. }\end{array}$ & $\begin{array}{c}\text { Udział } \\
\text { pow. } \\
\text { zabudowy }\end{array}$ & $\begin{array}{c}\text { Pow. wolna } \\
\text { od zabudowy } \\
\text { na } 1 \mathrm{~m}^{2} \\
\text { pow. ogólnej }\end{array}$ & $\begin{array}{c}\text { Pow. } \\
\text { ogólna na } \\
\text { mieszkańca }\end{array}$ & $\begin{array}{c}\text { Gęstość } \\
\text { zaludnienia } \\
\text { na } \mathrm{km}^{2}\end{array}$ \\
\hline $82,4 \mathrm{ha}$ & $0,79 \mathrm{mln} \mathrm{m}^{2}$ & 0,96 & 5 & $20,05 \%$ & $0,83 \mathrm{~m}^{2}$ & Ok. $85 \mathrm{~m}^{2}$ & 10923 os. \\
\hline
\end{tabular}

Wyniki ze względu na skalę i charakter obszaru nawiązujący do modelowej jednostki sąsiedzkiej, będą porównywane do wskaźników dla całej dzielnicy IBD Songdo oraz Osiedla Tysiąclecia.

W zestawieniu z IBD na uwagę zasługuje podobna intensywność zabudowy oraz gęstości zaludnienia, jednak fakt, że średnia ważona liczba kondygnacji jest około trzykrotnie niższa sprawia, że udział powierzchni zabudowy jest ponad trzykrotnie wyższy niż, co sprawia, że dzielnica posiada zdecydowanie mniej terenów rekreacyjnych, parkowych.

W porównaniu do śląskiego osiedla można stwierdzić, że w ujęciu matematycznym obydwie struktury urbanistyczne są zbliżone, niemiecka dzielnica jest jedynie o $2 \%$ bardziej zabudowana. Jest to ciekawy wynik, gdyż na podstawie analizy wizualnej, powstaje wrażenie, że postmodernistyczna struktura zorganizowana w formie kwartałów i ich półprywatnych wnętrz jest bardziej zabudowana, bardziej miejska niż zatopione w ogólnodostępnej z założenia rekreacyjnej, parkowej przestrzeni zielonej. 


\section{PODSUMOWANIE I WNIOSKI}

Nie sposób porównać Songdo z innym miastem. Skala przedsięwzięcia inwestycyjnego i fakt realizacji na terenie pozbawionym kontekstu sprawia, że można mówić o nowym zjawisku w urbanistyce. Ciężko odpowiedzieć na pytanie, czy analizowane azjatyckie miasto będzie rozliczone przez historię jako najbardziej reprezentatywny przykład trendu Smart City w urbanistyce, o ile taki zostanie kiedykolwiek wyodrębniony.

Na uwagę zasługuje zwrócenie się projektantów bardziej w stronę założeń modernistycznych, które zostały skrytykowane, uznane za pozbawione ludzkiej skali niż w stronę chętnie stosowanych, rozwiązań postmodernistycznych, kwartałowych oraz sposób kreowania miasta w oparciu o mniejsze, autonomiczne jednostki sąsiedzkie, spięte ze sobą za pomocą rozległych terenów parkowych i rekreacyjnych.

Decyzje projektowe z pewnością były podejmowane w oparciu o szerokie analizy ekonomiczne. Jednak finalnie w założeniu miało powstać miasto idealne XXI w. pozbawione wad, zaprogramowana i kontrolowana maszyna - kraina szczęścia, będąca przykładem dla innych, w jaką stronę powinien następować zrównoważony rozwój miast.

Powstaje obawa, że realizowane w wyniku jednego projektu miasta będą do siebie bardzo podobne, staną się bardziej wydajne, a mniej zaskakujące, charyzmatyczne i pełne niepowtarzalnego uroku. W związku z tym należy spróbować odpowiedzieć na pytanie jaka jest rola architekta, urbanisty jako ambasadora zurbanizowanej przestrzeni Smart City wobec społeczeństwa. Wtedy być może okaże się, czy to pojęcie można zdefiniować i zamknąć w sztywne ramy konkretnej typologii zabudowy, czy stanie się ono doktryną przyświecającą tworzeniu projektów struktur miejskich poprzez bardzo elastyczne dopasowanie się do zmiennych, na całym świecie innych potrzeb przyszłych mieszkańców, o czym w swoich esejach pisał Christopher Alexander ${ }^{12}$. Czy świadomość słów Winstona Churchilla, że najpierw my kształtujemy budynki, a później budynki kształtują nas, a nawet całe społeczeństwa, spowoduje bardziej indywidualne i zdrowe podejście do kreowania struktur urbanistycznych, czy dzięki temu „Smart City” stanie się nowym trendem w kreowaniu miast, czy zostanie określone mianem chwytliwego sloganu, za którym widnieje lobby informatyczne gromadzące olbrzymią ilość cennych i wartościowych dla wielu korporacji marketingowych informacji o każdym z nas. 
69

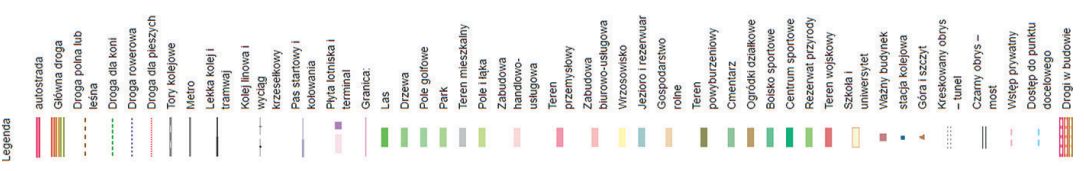

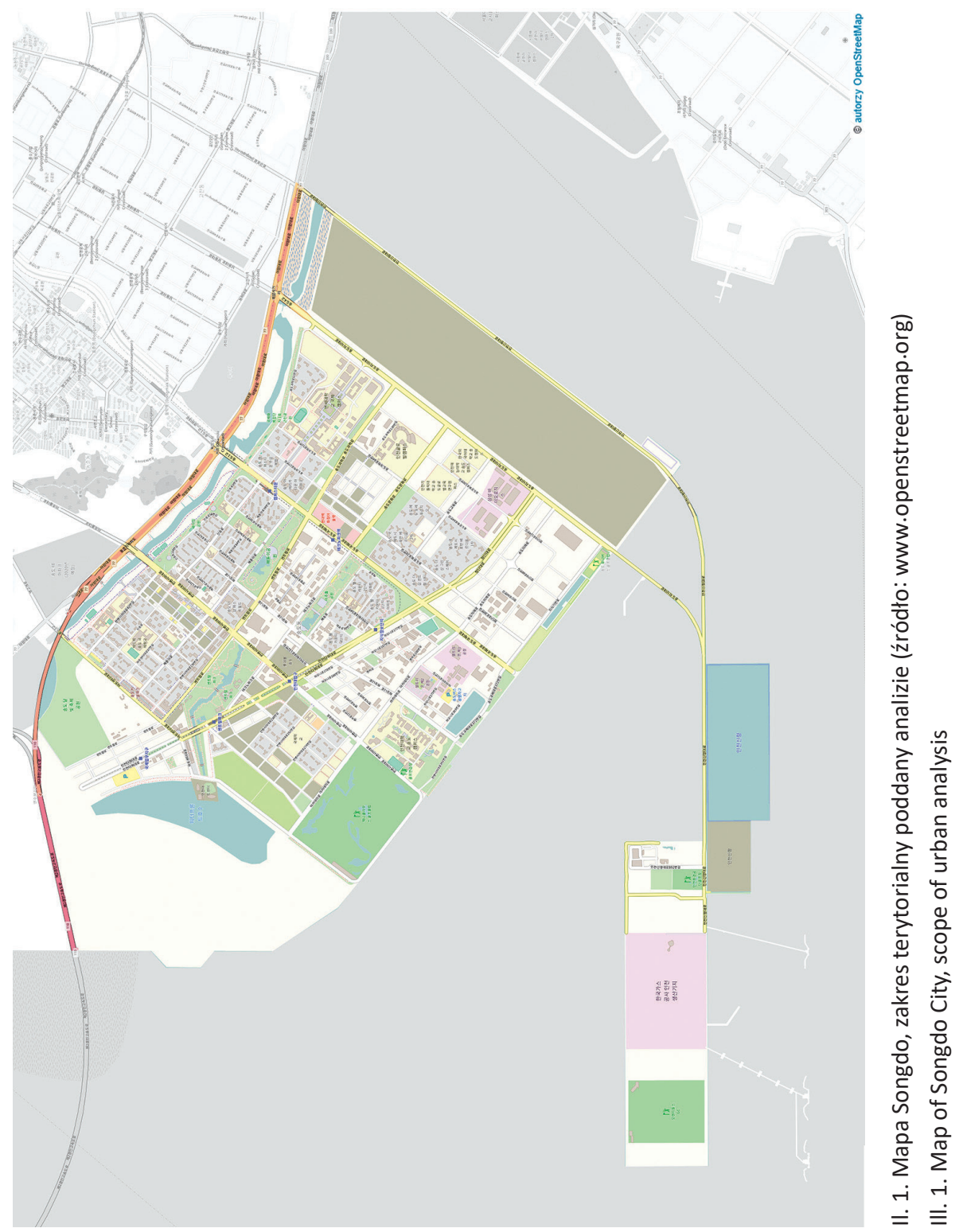




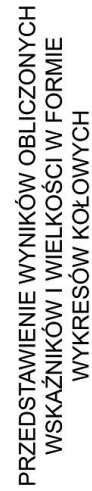

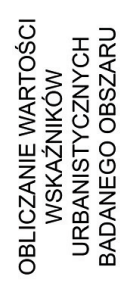

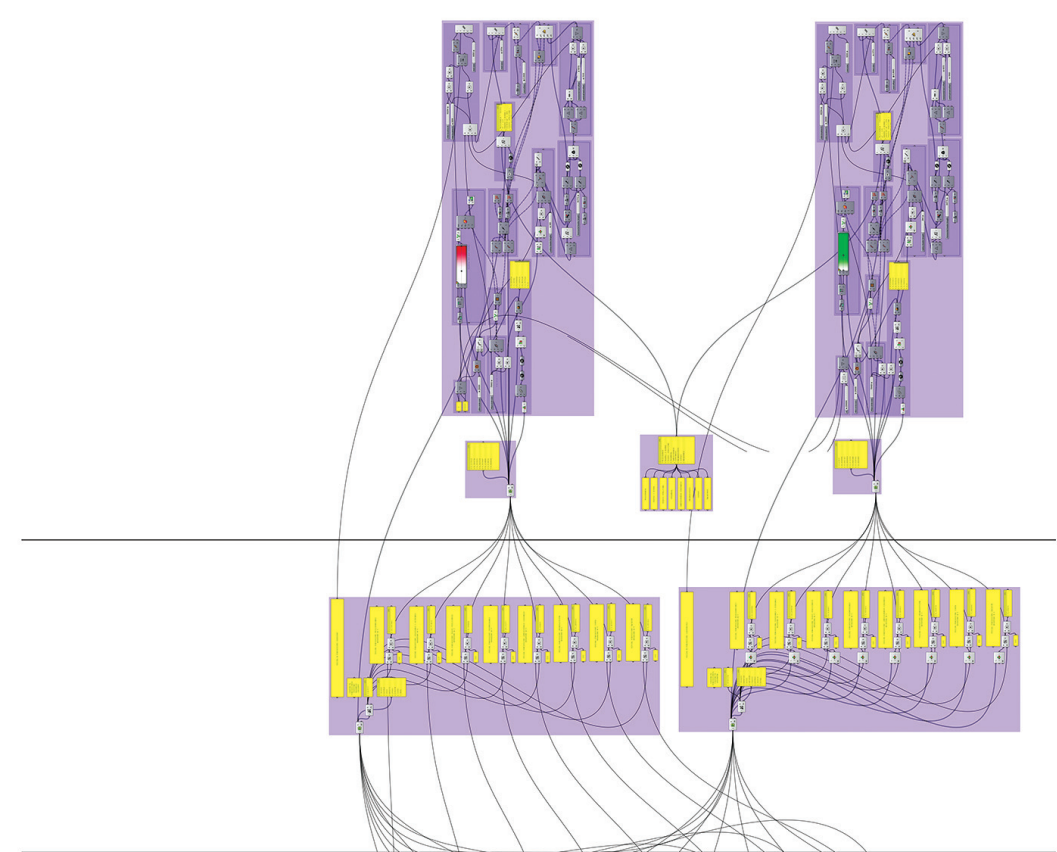

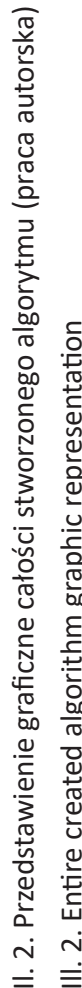

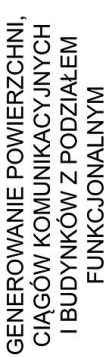
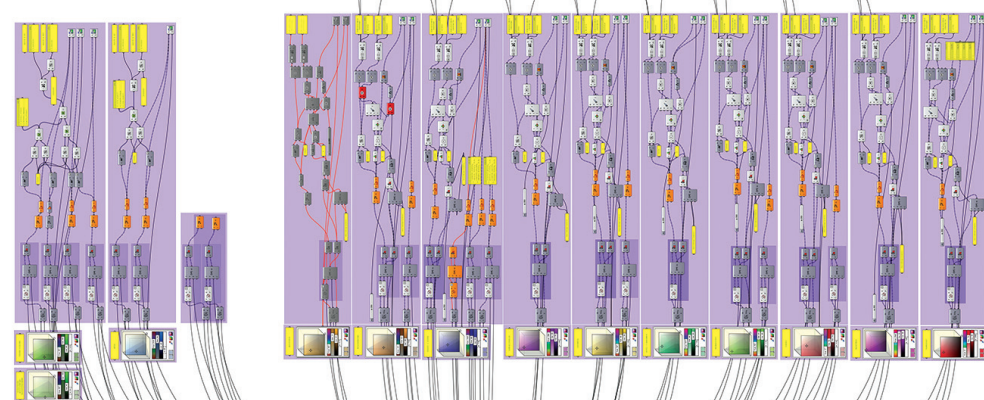

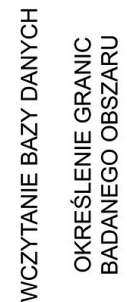




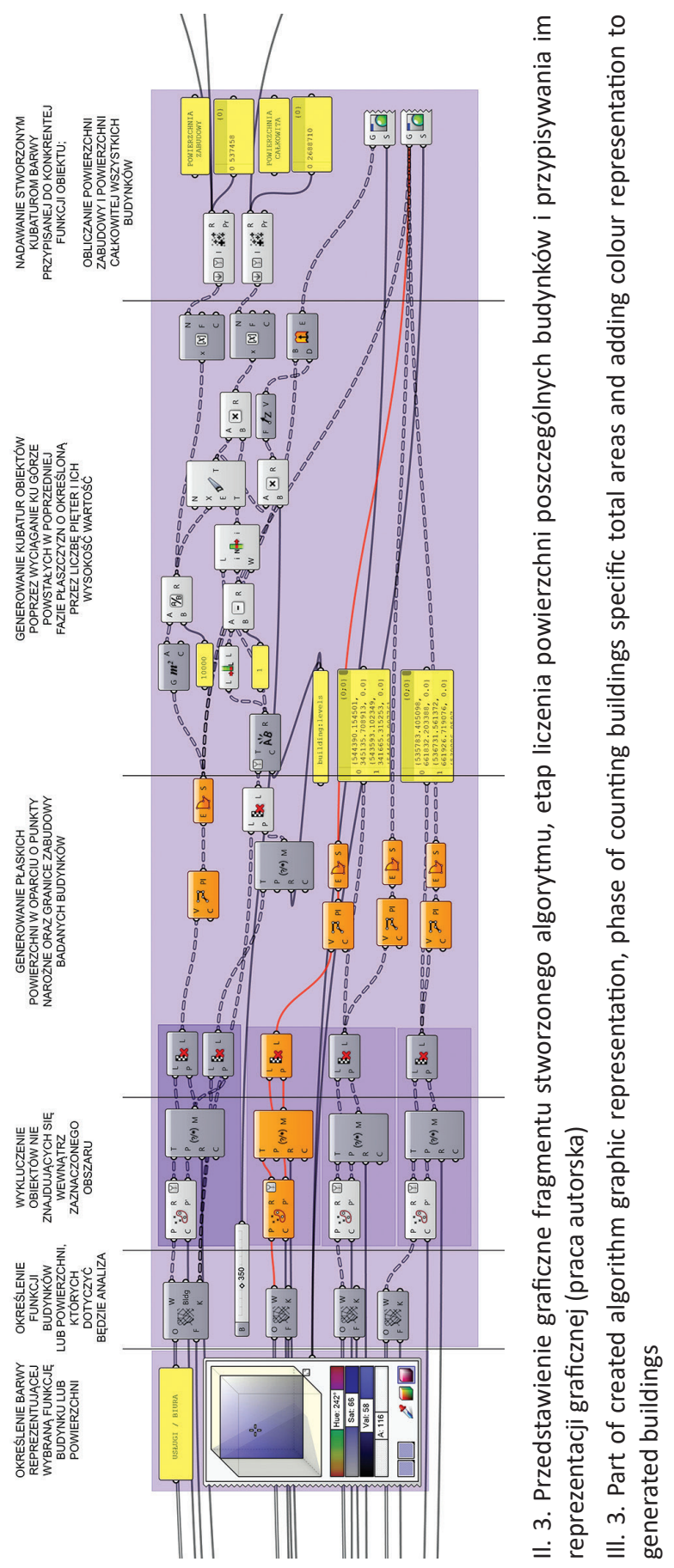




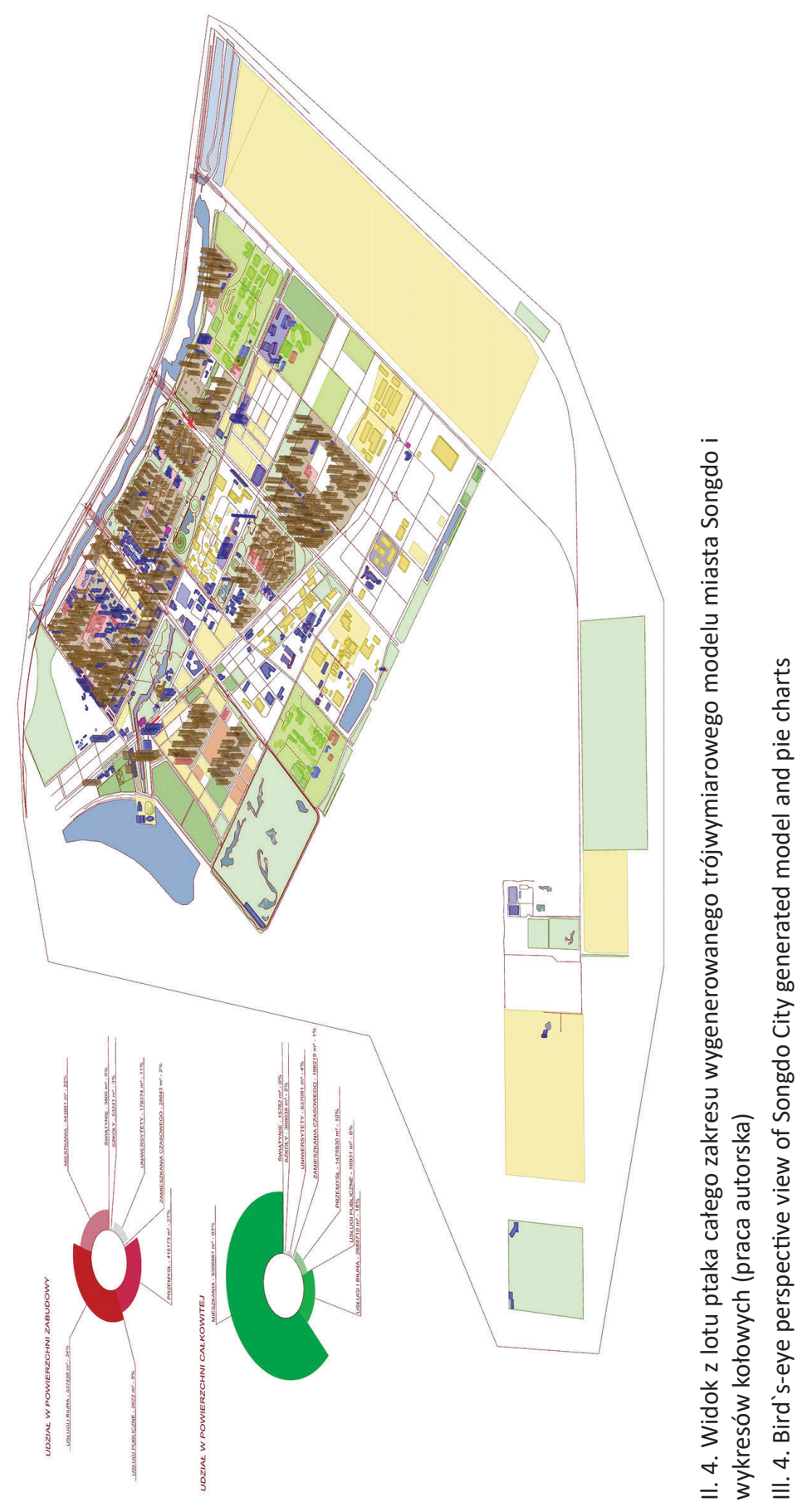




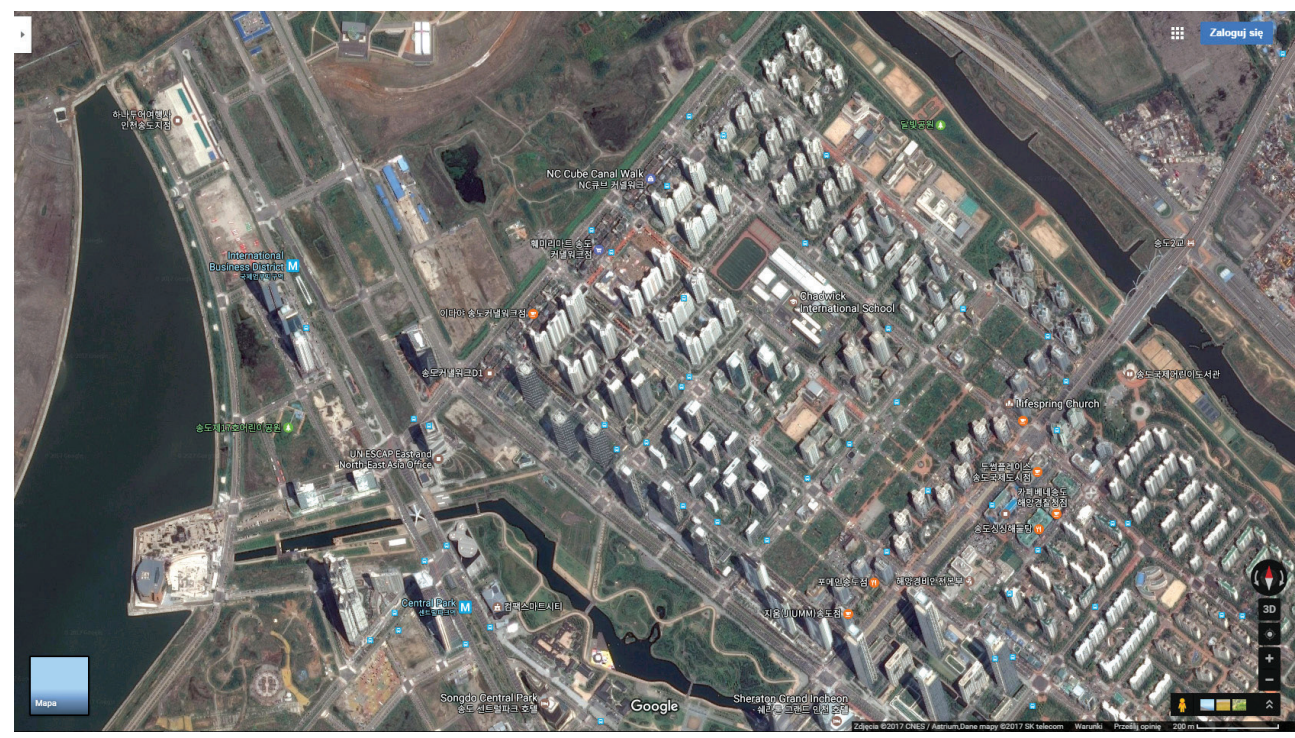

II. 5. Zdjęcie satelitarne fragmentu miasta Songdo ukazujące stan aktualny (źródło: www.maps.google.pl)

III. 5. Present satellite imagery of part of Songdo City

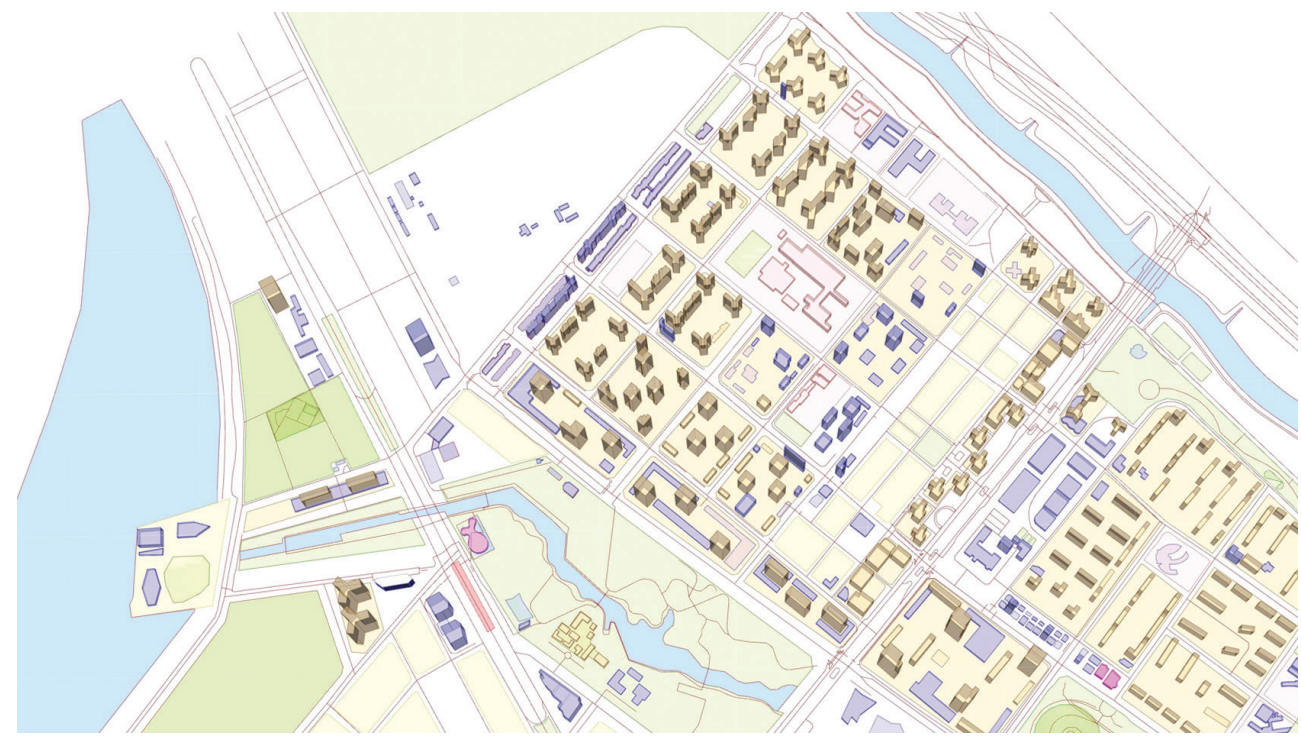

II. 6. Ujęcie perspektywiczne z wygenerowanego trójwymiarowego modelu miasta Songdo (praca autorska)

III. 6. Perspective view of Songdo City generated model 


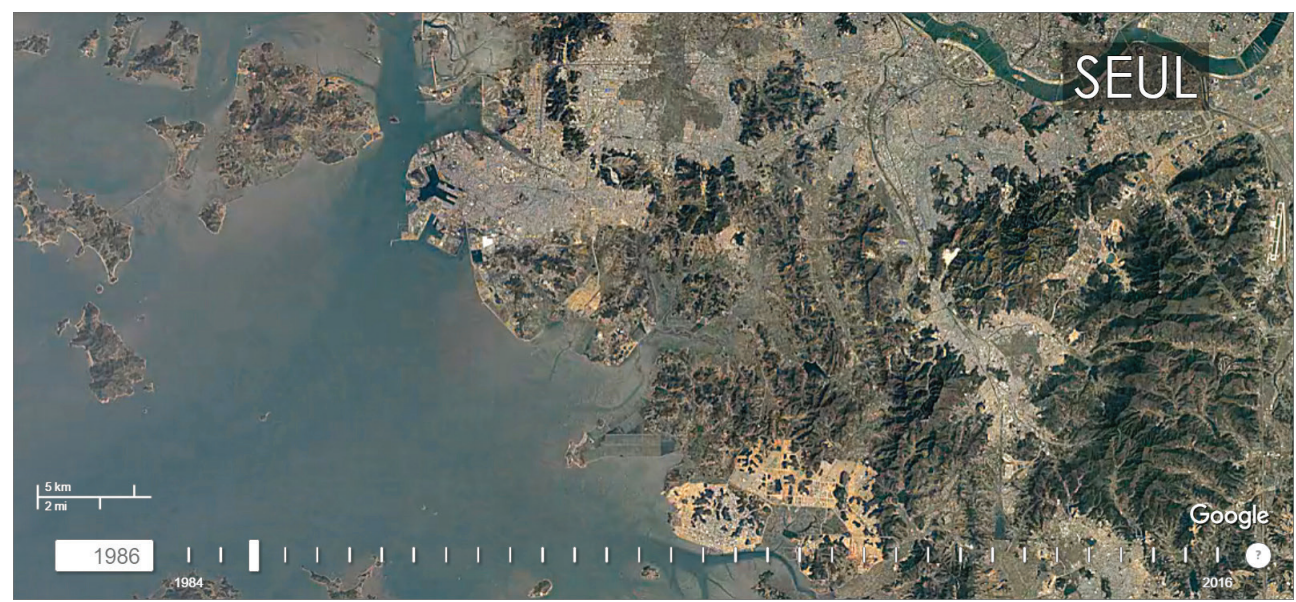

II. 7. Zdjęcie satelitarne z 1986 roku przedstawiające historyczny stan linii brzegowej (źródło: www.earthengine.google.com/timelapse)

III. 7. Satellite imagery from 1986 of Seul's bay historic coast line

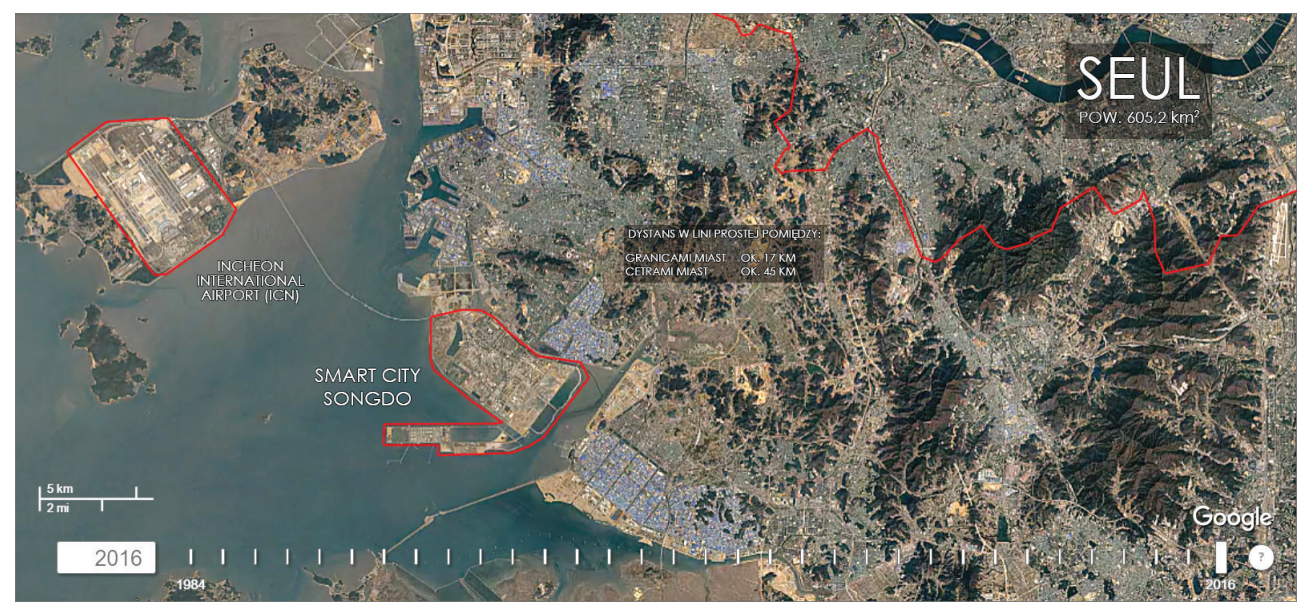

II. 8. Grafika ze zdjęciem satelitarnym z 2016 roku przedstawiająca lokalizację miasta Songdo i obecną linię brzegową (źródło: www.earthengine.google.com/timelapse)

III. 8. Satellite imagery from 2016 of Seul's bay present coast line and localisation of Songdo City 
II. 9. Struktura zabudowy miasta Songdo (praca autorska)

III. 9. Urban structure scheme of Songdo City

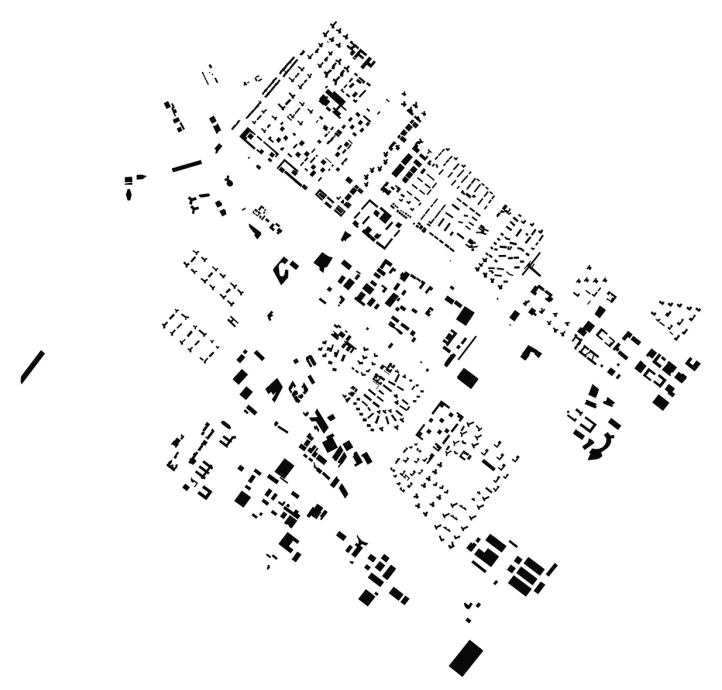

II. 10. Analiza zacieniania w mieście Songdo wykonana w dniu równonocy wiosennej

(praca autorska)

III. 10. Shading analysis of Songdo City on 21st of march

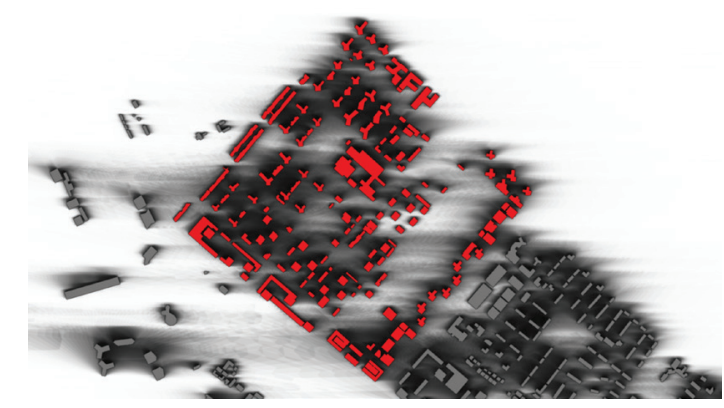

II. 11. Analiza zacieniania w kwartale zabudowy w mieście Songdo wykonana w dniu równonocy wiosennej (praca autorska)

III. 11. Shading analysis of Songdo`s City urban block on 21st of march 


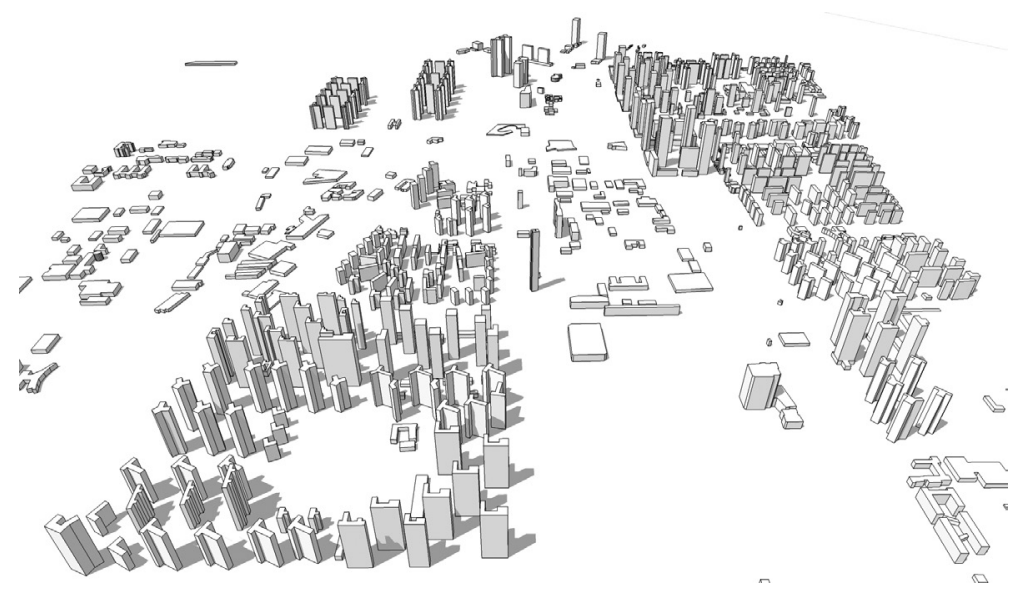

II. 12. Ujęcie perspektywiczne z lotu ptaka modelu miasta Songdo (praca autorska)

III. 12. Bird`s-eye perspective view of Songdo City generated model

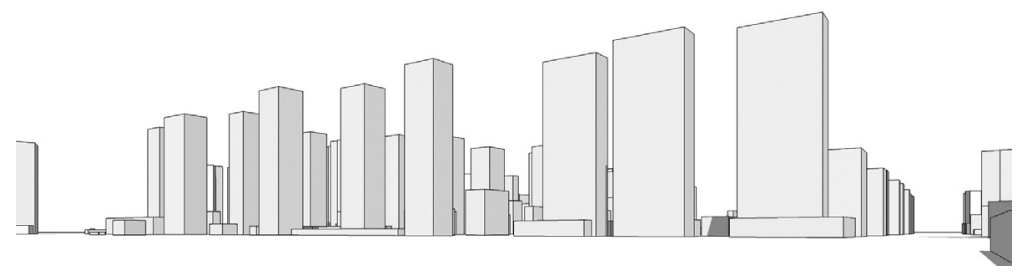

II. 13. Ujęcie z perspektywy człowieka z zewnętrza analizowanej jednostki sąsiedzkiej w mieście Songdo (praca autorska)

III. 13. Human-eye perspective view from exterior of examined neighbourhood unit in Songdo City

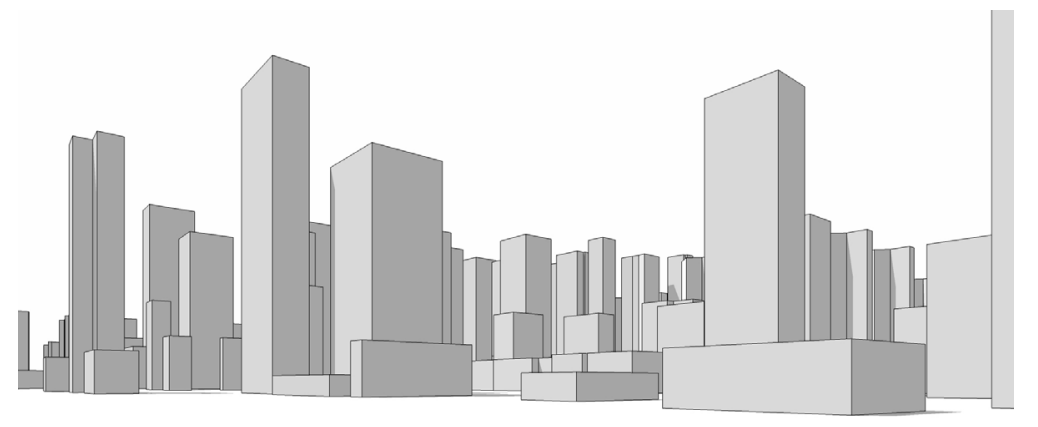

II. 14. Ujęcie z perspektywy człowieka wnętrza analizowanej jednostki sąsiedzkiej w mieście Songdo (praca autorska)

III. 14. Human-eye perspective view from interior of examined neighbourhood unit in Songdo City 


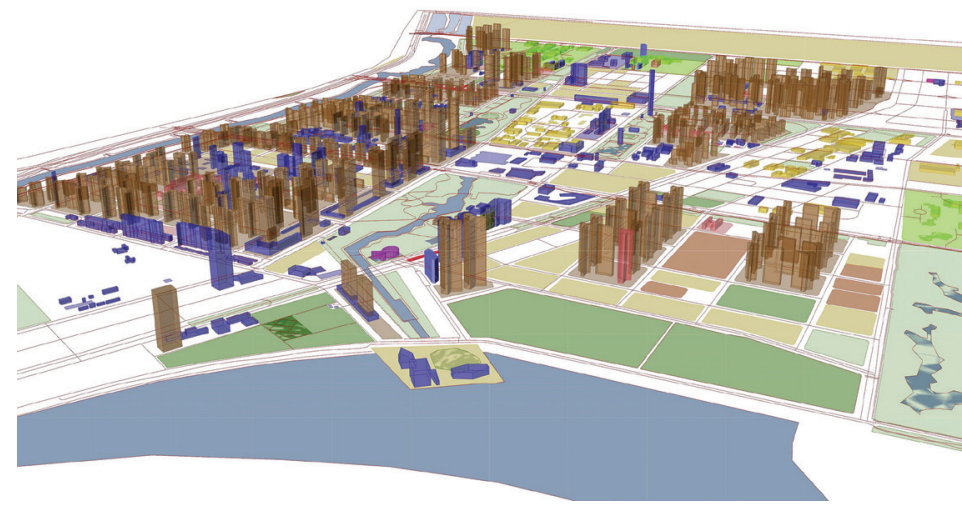

II. 15. Widok z lotu ptaka trójwymiarowego modelu całego miasta Songdo III. 15. Bird`s-eye perspective view of whole Songdo City generated model UDZIAL W POWIERZCHNI ZABUDOWY

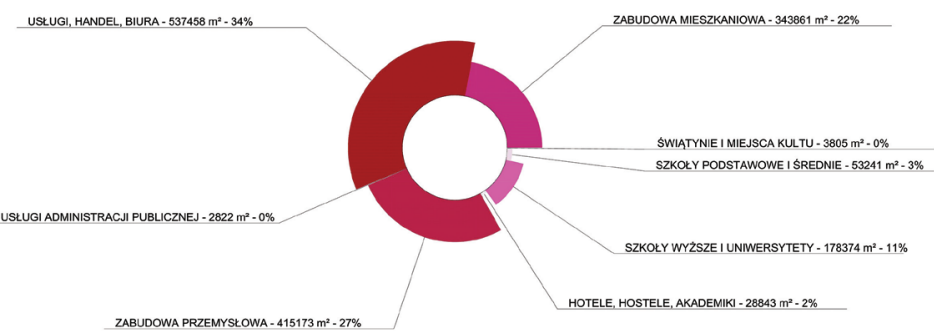

II. 16. Wykres (nr 1) udziału funkcjonalnego powierzchni zabudowy dla całego miasta (praca autorska) III. 16. The pie chart ( $\mathrm{nr} 1$ ) of function participation in total gross covered area of buildings in whole city

UDZIAL W POWIERZCHNI CAŁKOWITEJ

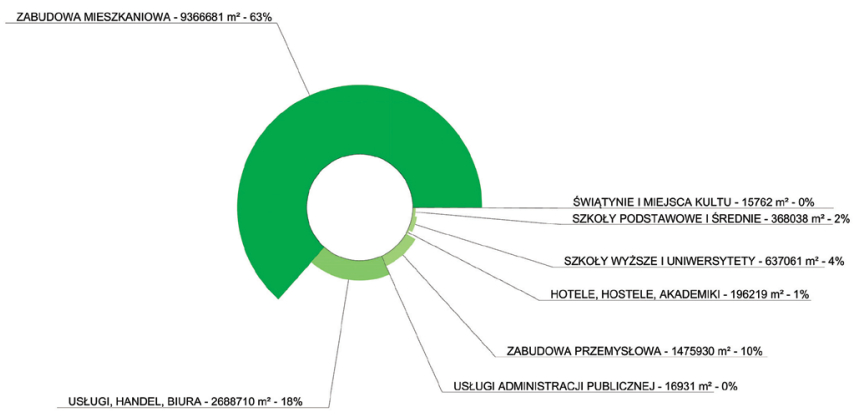

II. 17. Wykres (nr 2) udziału funkcjonalnego powierzchni całkowitej dla całego miasta (praca autorska) III. 17. The pie chart ( $n r 2$ ) of function participation in total gross floor area of buildings in whole city 


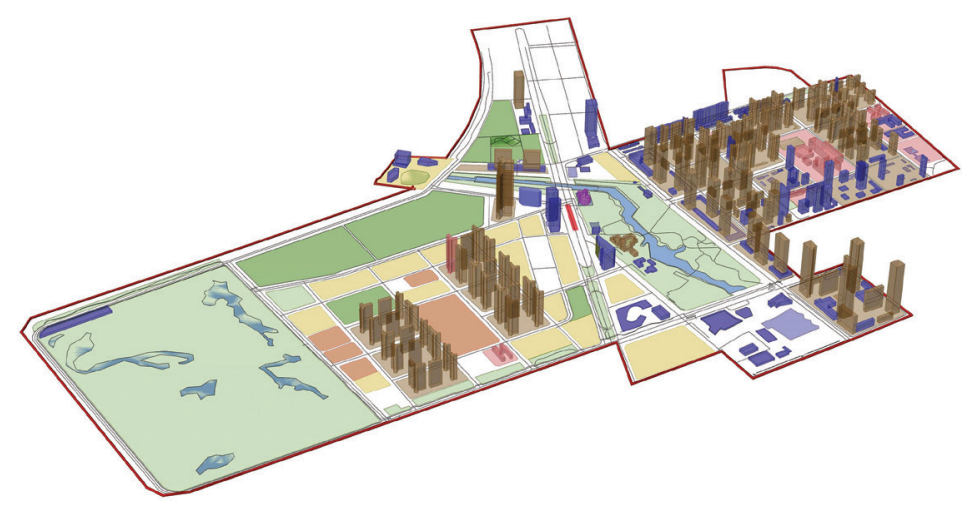

II. 18. Ujęcie perspektywiczne trójwymiarowego modelu dzielnicy IBD Songdo (praca autorska)

III. 18. Bird`s-eye perspective view of Songdo City International Business District generated model

UDZIAL W POWIERZCHNI ZABUDOWY

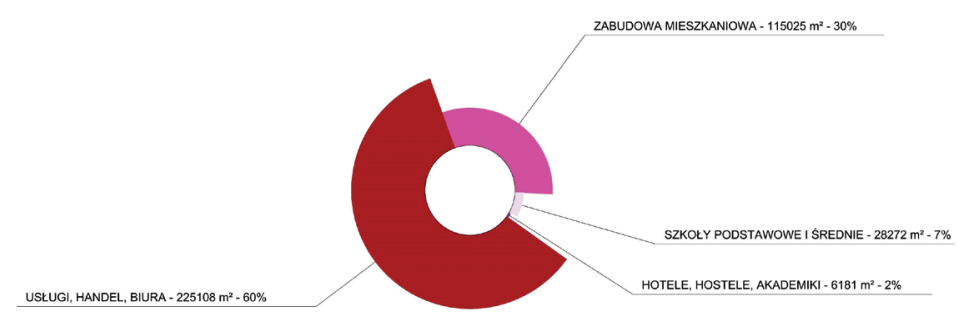

II. 19. Wykres (nr 1) udziału funkcjonalnego powierzchni zabudowy dla dzielnicy IBD (praca autorska)

III. 19. The pie chart ( $n r 1$ ) of function participation in total gross covered area of buildings in Songdo IBD

UDZIAK W POWIERZCHNI CAKKOWITEJ

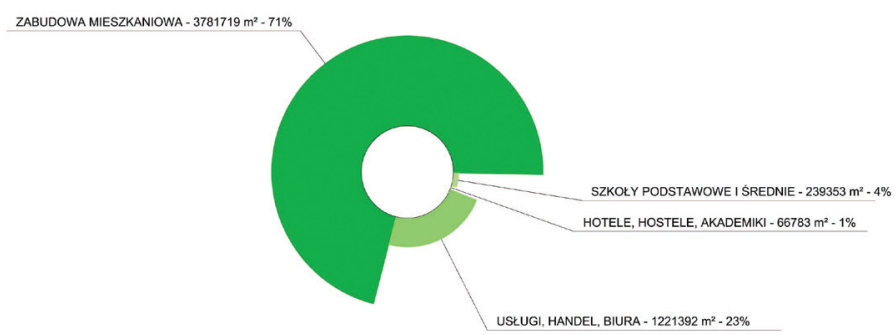

II. 20. Wykres ( $\mathrm{nr} 2$ ) udziału funkcjonalnego powierzchni całkowitej dla dzielnicy IBD (praca autorska) III. 20. The pie chart ( $\mathrm{nr} 2$ ) of function participation in total gross floor area of buildings in Songdo IBD 


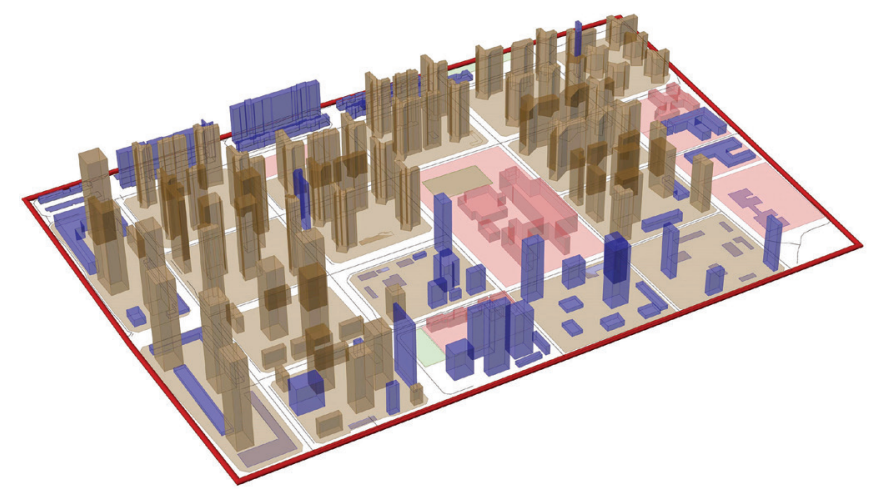

II. 21. Ujęcie perspektywiczne trójwymiarowego modelu kwartału zabudowy w dzielnicy IBD Songdo (praca autorska)

III. 21. Bird`s-eye perspective view of Songdo City International Business District's urban block generated model UDZIA W POWIERZCHNI ZABUDOWY

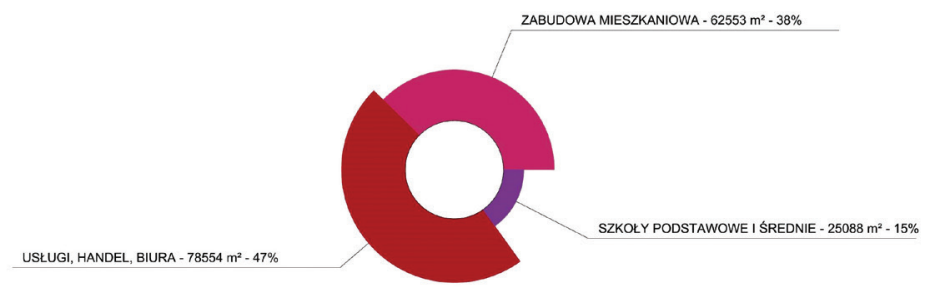

II. 22. Wykres (nr 1) udziału funkcjonalnego powierzchni zabudowy dla kwartału zabudowy w dzielnicy IBD Songdo (praca autorska)

III. 22. The pie chart ( $n r 1$ ) of function participation in total gross covered area of buildings in Songdo IBD`s urban block

UDZIAL W POWIERZCHNI CALKOWITEJ

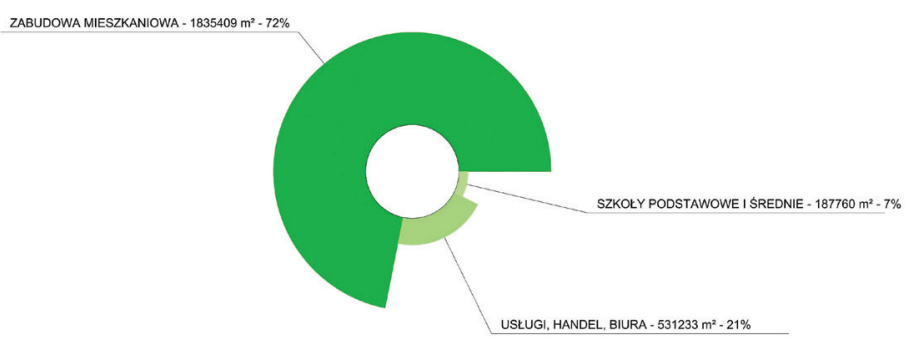

II. 23. Wykres (nr 2) udziału funkcjonalnego powierzchni zabudowy dla kwartału zabudowy w dzielnicy IBD Songdo (praca autorska)

III. 23. The pie chart ( $\mathrm{nr} 2$ ) of function participation in total gross floor area of buildings in Songdo IBD`s urban block 


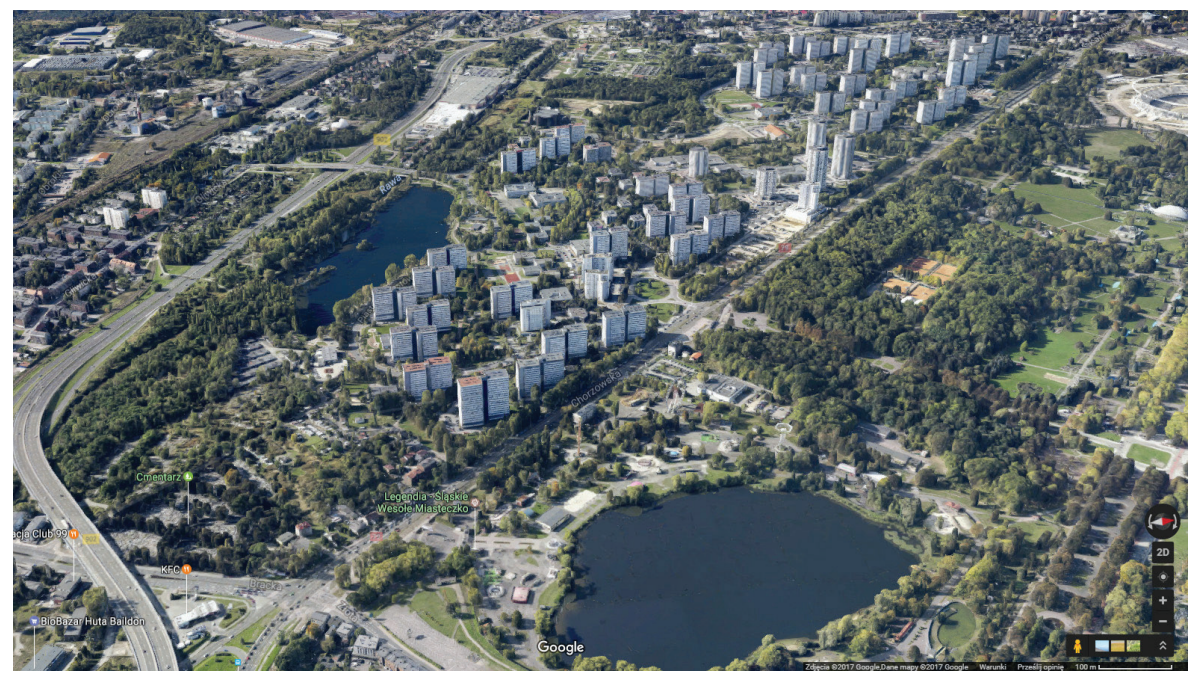

II. 24. Grafika ze zdjęciem satelitarnym z 2017 roku przedstawiająca na trójwymiarowym ujęciu charakter i strukturę zabudowy Osiedla Tysiąclecia w Katowicach, Polska (źródło: www.google.pl/maps)

III. 24. Graphic with satellite imagery from 2017 of Settlement Unit in Katowice, Poland

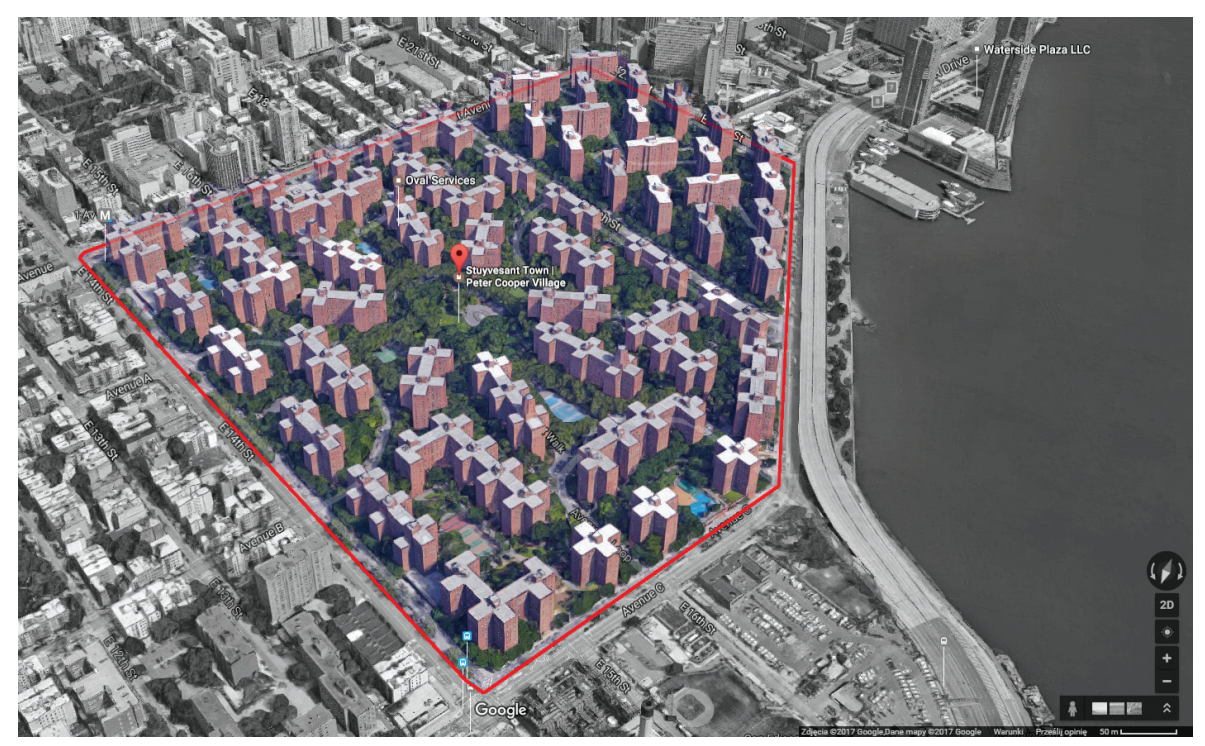

II. 25. Grafika ze zdjęciem satelitarnym z 2017 roku przedstawiająca na trójwymiarowym ujęciu charakter i strukturę zabudowy Stuyvesant Town - Peter Cooper Village, Manhattan, Nowy Jork, USA (źródło: www.google.pl/maps)

III. 25. Graphic with satellite imagery from 2017 of Stuyvesant Town - Peter Cooper Village, NY, USA 


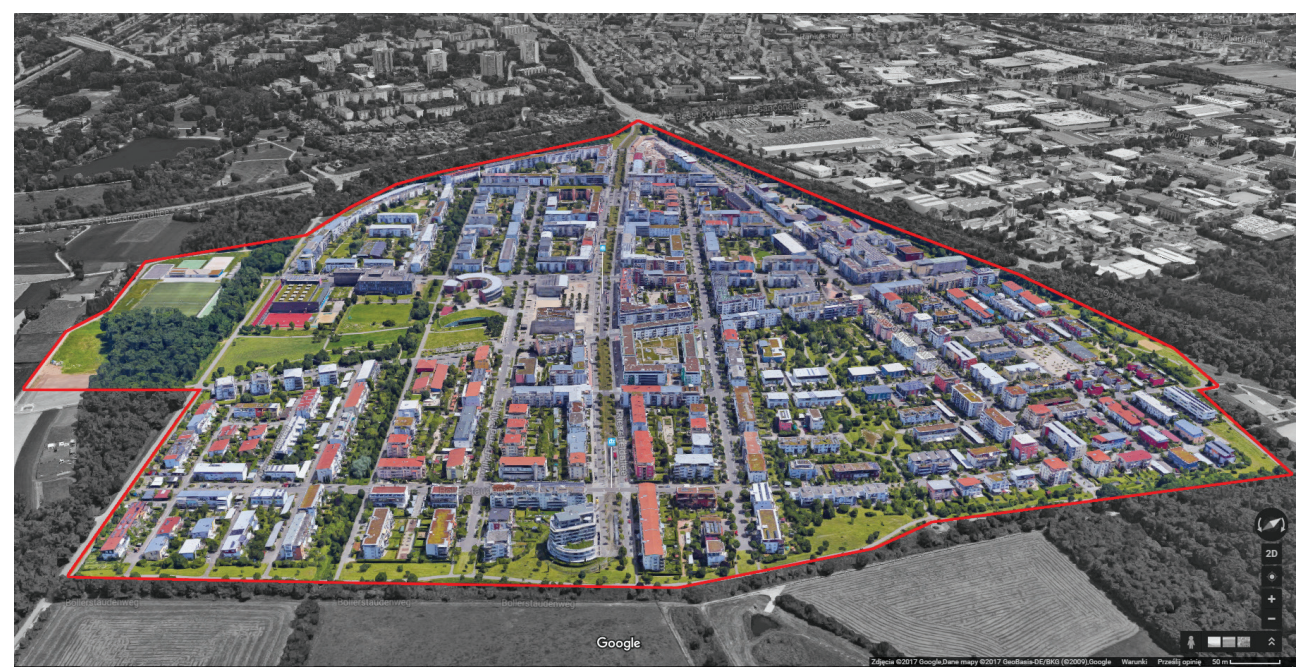

II. 26. Grafika ze zdjęciem satelitarnym z 2017 roku przedstawiająca na trójwymiarowym ujęciu charakter i strukturę zabudowy dzielnicy Rieselfeld we Fryburgu, Niemcy (źródło: www.google.pl/maps)

III. 26. Graphic with satellite imagery from 2017 of Rieselfeld neighbourhood in Freiburg, Germany

\begin{tabular}{|c|c|c|c|c|c|c|c|c|}
\hline $\begin{array}{l}\text { NAZWA BADANEJ } \\
\text { STRUKTURY } \\
\text { URBANISTYCZNEJ }\end{array}$ & $\begin{array}{c}\text { POW. } \\
\text { TERENU } \\
\text { INWESTYCJI }\end{array}$ & $\begin{array}{l}\text { POW. } \\
\text { OGÓLNA }\end{array}$ & $\begin{array}{l}\text { INTENSYW. } \\
\text { ZABUDOWY }\end{array}$ & $\begin{array}{c}\text { ŚREDNIA } \\
\text { WAŻONA } \\
\text { LICZBA KOND. }\end{array}$ & $\begin{array}{l}\text { UDZIAt } \\
\text { POW. } \\
\text { ZABUDOWY }\end{array}$ & $\begin{array}{l}\text { POW. WOLNA } \\
\text { OD ZABUDOWY } \\
\text { NA } 1 \mathrm{~m}^{2} \text { POW. } \\
\text { OGÓLNEJ }\end{array}$ & $\begin{array}{l}\text { POW. OGÓLNA } \\
\text { NA MIESZKAŃCA }\end{array}$ & $\begin{array}{c}\text { GĘSTOŚĆ } \\
\text { ZALUDNIENIA } \\
\text { NA km² }\end{array}$ \\
\hline $\begin{array}{l}\text { SONGDO, KOREA PŁD, } \\
\text { CAŁE MIASTO }\end{array}$ & 2830 ha & $14,75 \mathrm{~m} / \mathrm{n} \mathrm{m}^{2}$ & 0,52 & 9,44 & $5,53 \%$ & $1,8 \mathrm{~m}^{2}$ & ok. $62 \mathrm{~m}^{2}$ & 5305 os. \\
\hline $\begin{array}{l}\text { SONGDO, KOREA PŁD, } \\
\text { DZIELNICA IBD }\end{array}$ & 600 ha & $5,4 \mathrm{mln} \mathrm{m}^{2}$ & 0,97 & 14 & $6,85 \%$ & $1,035 \mathrm{~m}^{2}$ & ok. $62 \mathrm{~m}^{2}$ & 11001 os. \\
\hline $\begin{array}{l}\text { SONGDO, KOREA PŁD, } \\
\text { KWARTA Z ZABUDOWY }\end{array}$ & 133 ha & $3,4 \mathrm{mln} \mathrm{m}^{2}$ & 2,56 & 15 & $16,65 \%$ & $0,32 \mathrm{~m}^{2}$ & ok. $62 \mathrm{~m}^{2}$ & 16014 os. \\
\hline $\begin{array}{l}\text { OSIEDLE TYSIACLECIA } \\
\text { W KATOWICACH }\end{array}$ & 188 ha & $1,975 \mathrm{mln} \mathrm{m}^{2}$ & 1,05 & 4,83 & $18,00 \%$ & $0,78 \mathrm{~m}^{2}$ & ok. $55 \mathrm{~m}^{2}$ & 12480 os. \\
\hline $\begin{array}{l}\text { STUYVESANT TOWN, } \\
\text { PETER COOPER } \\
\text { VILLAGE, NY, USA }\end{array}$ & 39 ha & $0,94 \mathrm{mln} \mathrm{m}^{2}$ & 2,4 & 13 & $22 \%$ & $0,32 \mathrm{~m}^{2}$ & ok. $43 \mathrm{~m}^{2}$ & 51910 os. \\
\hline $\begin{array}{l}\text { RIESELFELD, } \\
\text { FRYBURG, NIEMCY }\end{array}$ & 82,4 ha & $0,79 \mathrm{mln} \mathrm{m}^{2}$ & 0,96 & 5 & $20,05 \%$ & $0,83 \mathrm{~m}^{2}$ & ok. $85 \mathrm{~m}^{2}$ & 10923 os. \\
\hline
\end{tabular}

II. 27. Zestawienie zbiorcze wartości poszczególnych wskaźników urbanistycznych badanych struktur

(praca autorska)

III. 27. Urban indicators of examined urban structures tabulation 


\section{PRZYPISY}

1 http://www.galeintl.com (dostęp: 11.05.2017).

2 https://www.kpf.com/projects/new-songdo-city (dostęp: 11.06.2017).

3 Dane na podstawie informacji zamieszczonych na portalu: http://songdoibd.com/about (dostęp: 12.05.2017).

4 Informacja nieaktualna, obecnie najwyższy budynek Korei Południowej znajduje się w Seulu.

5 C.K. Pawłowski, Tony Garnier - Pionnier de l'urbanisme du XXème siècle, Les Créations du Pélican, Lyon 1993.

6 J. Jenger, Le Corbusier. L'architecture pour émouvoir, Gallimard, Paris 1999.

7 H. Ebenezer, Garden Cities of Tomorrow, London 1902.

8 J. Gehl, Życie między budynkami. Użytkowanie przestrzeni publicznych, wyd. RAM, Kraków 2009, s. 19.

9 K.A. Lynch, The image of the City, The MIT Press, 1960.

10 Prezydent Miasta Katowice, Raport o stanie miasta Katowice, Katowice 2005.

${ }^{11}$ Na podstawie danych z portalu internetowego: https://nextdoor.com/neighborhood/ stuyvesanttowneast--new-york--ny (dostęp: 11.06.2017).

${ }^{12}$ C. Alexander, A Pattern Language: Towns, Buildings, Construction, Oxford University Press 1977.

\section{BIBLIOGRAFIA}

\section{Wydawnictwa książkowe}

Alexander C., A Pattern Language: Towns, Buildings, Construction, Oxford University Press 1977, ISBN 0-19-501919-9.

Brook D., A History of Future Cities, Nowy Jork, W.W. Norton \& Co Inc., 2013.

Gehl J., Życie między budynkami. Użytkowanie przestrzeni publicznych, wyd. RAM, Kraków 2009.

Hollis L., Cities Are Good For You, The Genius Of The Metropolis, Bloomsbury Publishing 2013, ISBN 978-14-0882-662-1.

Howard E., Garden Cities of Tomorrow, London 1902.

Jenger J., Le Corbusier. L'architecture pour émouvoir, Gallimard, Paris 1999.

Lynch K.A., The image of the City, The MIT Press, 1960.

Pawłowski C.K., Tony Garnier - Pionnier de l'urbanisme du XXème siècle, Les Créations du Pélican, Lyon 1993.

Townsend A.M., Smart Cities: Big Data, Civic Hackers, and the Quest for a New Utopia, W.W. Norton \& Company, Inc. 2013, ISBN 978-0-393-34978-8. 
Wejchert K., Elementy kompozycji urbanistycznej, Arkady, Warszawa 2008, ISBN 83-2134494-2.

Zuckerman E., Rewire, Digital Cosmopolitans In The Age Of Connection, Nowy Jork, W.W. Norton \& Co Inc. 2013, ISBN 978-03-930-8283-8.

\section{Artykuły publikowane w internecie:}

Arup Connect, How Should We Implement Smart Cities, ArchDaily, 2014, http://www.archdaily. com/476803/how-should-we-implement-smart-cities (dostęp: 07.06.2017).

AD Editorial Teamt, AD Essentials: Smart Cities, ArchDaily, 2015, http://www.archdaily. com/769341/ad-essentials-smart-cities (dostęp: 07.06.2017).

Lindsay G., 5 Global Cities of the Future, INC, 2015, http://www.greglindsay.org/articles/5_global_cities_of_the_future (dostęp: 07.06.2017).

Lindsay G., Cities of the Sky,WSJ, 2011, http://www.greglindsay.org/articles/cities_of_the_sky (dostęp: 07.06.2017).

Lindsay G., The New New Urbanism: New Songdo \& Creating Cities From Scratch, Fast Company, 2010, http://www.greglindsay.org/articles/the_new_new_urbanism_creating_cities_from_scratch (dostęp: 07.06.2017).

Lindsay G., Not-So-Smart Cities, The New York Times, 2011, http://www.greglindsay.org/ articles/not-so-smart_cities (dostęp: 07.06.2017).

Wakefield J., Tomorrow's cities: Wthat's like to live in a smart city?, BBC News, 2013, http:// www.bbc.com/news/technology-23757739 (dostęp: 07.06.2017).

\section{Strony internetowe}

www.earthengine.google.com/timelapse (dostęp: 11.05.2017).

www.galeintl.com (dostęp: 11.05.2017).

www.google.pl/maps (dostęp: 11.05.2017).

www.kpf.com/projects/new-songdo-city (dostęp: 11.06.2017).

www.newcities.org/cityquest-songdo-south-korea-conceptualized-ultimate-smart-sustaina-

ble-city (dostęp: 11.06.2017).

www.nextdoor.com/neighborhood/stuyvesanttowneast--new-york--ny (dostęp: 11.06.2017). www.openstreetmap.org (dostęp: 20.05.2017).

www.songdoibd.com (dostęp: 12.05.2017).

www.thenational.ae/business/economy/songdo-blazes-smart-city-trail (dostęp: 11.06.2017). 